\title{
Analyst Optimism and Incentives under Market Uncertainty
}

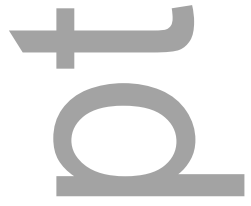

\author{
Jin Woo Chang ${ }^{1}$ \\ Hae mi Choi ${ }^{2}$ \\ Abstract
}

We examine how analysts' changing incentives driven by changes in market uncertainty affect their forecast optimism. Analysts issue more optimistically biased earnings forecasts and buy recommendations under high market uncertainty (VIX). The lower reputational costs and larger benefits of optimistic output explain the increased optimistic output: Analysts are less likely to be penalized for inaccuracy and can stimulate more trading activity from optimistically biased output when market uncertainty is high. We find that the likelihood of analysts' turnover decreases, while the trading volume associated with optimistic output increases, with VIX. No evidence suggests that analysts' self-selection affects our findings on optimism and market uncertainty.

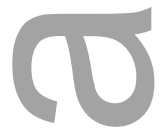

JEL classification codes: G24; G29; G14; M40

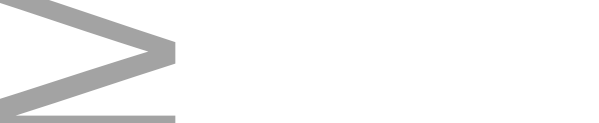

Keywords: Sell-side Analysts; Optimism; Market Uncertainty; Reputation

\section{Introduction}

Starting with Schipper (1991) and Brown (1993), and more recently Ramnath, Rock, and Shane (2008) and Bradshaw (2011), researchers have suggested that the analyst-forecasting literature

\footnotetext{
${ }^{1}$ Jin Woo Chang, Ross School of Business, University of Michigan, email: jinwooch@ umich.edu.

${ }^{2}$ Hae mi Choi, Quinlan School of Business, Loyola University Chicago, email: hchoi2@luc.edu, Ph (o): (312) 915-6320.

We thank participants at the Financial Management Association (FMA) meetings (2013), participants at the Midwest Management Association (MFA) meetings (2015), and numerous colleagues for their helpful comments. We especially thank Jonathan Clarke for providing us with the All-star analyst data and an anonymous referee, Swasti Gupta-Mukherjee, Kyle Handley, Bob Kolb, Srini Krishnamurthy (editor), Marco Navone, Tom Nohel, Jagadeesh Sivadasan, Steven Todd, Qiaoqiao Zhu for their input. All errors are our own.
}

This is the author manuscript accepted for publication and has undergone full peer review but has not been through the copyediting, typesetting, pagination and proofreading process, which may lead to differences between this version and the Version of Record. Please cite this article as doi: 10.1111/fire.12138.

This article is protected by copyright. All rights reserved. 
focus more on the context in which analysts make their decisions. Schipper (1991) and Brown (1993) emphasize the roles of macroeconomic factors in formulating stock price forecasts and recommendations. Ramnath, Rock, and Shane (2008) describe the analyst reporting environment, in which macroeconomic conditions are an important factor in obtaining and analyzing information to produce earnings forecasts and stock recommendations. Stock-market volatility is viewed as a marketbased measure of economic uncertainty (Bloom, 2009).

Volatile market conditions not only increase firms' earnings volatility, but also increase the volatility of information signals about a firm's value, since the firm is not independent of the business conditions in which it operates. This increase in the operational and information uncertainty affects all analysts in gathering information about the effect of market-level factors on firm performance (Amiram, Landsman, Owens, and Stubben, 2014; Loh and Stulz, 2015). In this context, this study examines whether the changes in market uncertainty affect sell-side analysts' optimism when they issue earnings forecasts and stock recommendations. Our goal is to shed new light on information contained in analysts' output and deepen our understanding of the role of analysts' incentives in their decision-making process.

Sell-side analysts face a tradeoff of incentives between issuing accurate forecasts to enhance their reputation and issuing optimistic forecasts to generate brokerage trading activity (Hayes, 1998; Hong, Kubik, and Solomon, 2000; Jackson, 2005; Cowen, Groysberg, and Healy, 2006; Beyer and Guttman, 2011) or to maintain a favorable relationship with firm management (Francis and Philbrick, 1993; Chen and Matsumoto, 2006; Mayew, 2008; Soltes, 2014; Brown, Call, Clement, and Sharp, 2015). Maintaining forecast accuracy enhances the analysts' reputation (Jackson 2005), enables analysts to move to larger brokerage houses (Hong and Kubik, 2003), and helps maintain job security (Hong, Kubik, and Solomon, 2000). Despite the reputational effects and career concerns associated with issuing optimistic forecasts, however, there is vast evidence that analysts are on average optimistically biased (Stickel, 1990; Abarbanell, 1991; Dreman and Berry, 1995; Chopra, 1998; Lim, 2001, among others). 
Most of the studies mentioned above examine the cross-sectional relationship between analysts' incentives and optimistic output. In particular, the literature has largely examined crosssectional measures of uncertainty (e.g., analyst-forecast dispersion) in studying analyst optimism (Ackert and Athanassakos, 1997). We extend the rich literature by taking a different approach and exploiting the time variation in market-level uncertainty to study analyst incentives and output. The benefits of using market-level uncertainty are two-fold. The first is that it allows us to exploit an exogenous variation in the analysts' information environment that affects all analysts, whereas crosssectional firm-level uncertainty measures may be correlated with analyst or firm characteristics. The second is that changes in market uncertainty provide a framework in which we can analyze the costs and benefits of analysts' optimistic output, by which we explain analysts' incentives for optimistic output. The scope of past empirical studies was largely limited to the benefits or the negative consequences of optimistic output. We contribute to the literature by enlarging the scope of our study to comprehensively investigating the effect of uncertainty on the costs and benefits of analysts' optimistic output, and the level of optimistic output, all at the individual analyst level.

We set up a simple framework in which an analyst decides the optimal level of optimistic output to maximize her utility, which is determined by her reputation level and trading commissions. Building on prior cross-sectional studies, we expect that an increase in optimistic output decreases the analyst's reputation but increases trading-commission benefits. When the level of uncertainty in the information environment changes, the marginal costs and benefits of issuing optimistic output also change, and therefore we expect the level of the analyst's optimism to vary accordingly over time. ${ }^{3}$

We use stock-market uncertainty as a proxy for the aggregate fundamental volatility of firms and, hence, the uncertainty of analysts' information environment in issuing earnings forecasts and stock recommendations. Market uncertainty is measured by the VIX index, which is the forwardlooking 30-day implied volatility of stock options. VIX is often used as a measure of stock-market

\footnotetext{
${ }^{3}$ Our marginal benefit-cost framework can easily be expanded to incorporate other benefits and costs of optimistic output. We use trading commission as an example of a benefit of issuing optimistic output in our main analysis, but we also examine other explanations such as maintaining a favorable relationship with management in section 5 .
} 
volatility or uncertainty. ${ }^{4}$ Bloom (2009) shows that stock-market volatility (VIX) is strongly correlated with firm and industry earnings growth dispersion, as well as GDP forecast dispersion. In a similar vein, Bekaert, Hoerova, and Lo Duca (2013) find that the fluctuations in VIX appear to heavily reflect movements in aggregate-level uncertainty.

We first examine the changes in the marginal cost and benefit of analysts' optimistic output to better understand the underlying changes in analysts' incentives. We hypothesize that the reputational cost of optimistic output decreases with the level of market uncertainty. When there is high uncertainty in the analysts' information environment, forecast inaccuracy can be attributed to noisy signals instead of the analysts' forecasting ability. To the extent that inaccurate forecasts lead to analysts' reputational loss, we expect that analysts with poor performance due to optimistically biased forecasts are more likely to be penalized by, for example, having to leave the industry (Hong, Kubik, and Solomon, 2000; Groysberg, Healy, and Maber, 2011) or move down to low-status brokerage firms (Hong and Kubik, 2003). Accordingly, we examine how the relationship between prior optimism and the likelihood of experiencing unfavorable career outcomes changes under different levels of market uncertainty. Indeed, we find that analysts are less likely to leave the industry or move to a low-status brokerage firm for optimistically biased forecasts when VIX is high.

We next examine whether the marginal benefit of optimistic output changes with uncertainty. Trading commissions are known to be an important benefit related to analysts' optimistic bias since optimistic forecasts generate more trading activity than pessimistic forecasts (Jackson, 2005; Beyer and Guttman, 2011). Recent studies show that analysts' forecasts and recommendations have a larger effect on investor beliefs during times of high market uncertainty (Amiram, Landsman, Owens, and Stubben, 2014; Loh and Stulz, 2015). Together, these prior studies lead us to expect that analysts can increase their utility by issuing optimistic forecasts during high-uncertainty periods, as their output would have a stronger effect on investor beliefs, which would lead to more trading commissions. Our empirical work provides evidence for the increase in marginal benefit of optimistic output when

\footnotetext{
${ }^{4}$ See Bloom, 2009; Bekaert, Hoerova, and Lo Duca, 2013; Nyborg and Östberg, 2014; Chung and Chuwonganant, 2014, among others.
}

This article is protected by copyright. All rights reserved. 
market uncertainty is high. We estimate the amount of trading activity around an analyst's forecastissue date and examine the association between the level of VIX, analysts' output, and trading activity. We find that when VIX is high, trading volume increases with the level of optimism in both earnings forecasts and stock recommendations.

Another important benefit of optimistic output is maintaining a favorable relationship with firm management to gain better access to inside information. We expect the demand for information from management to be stronger for firms with more firm-level information relative to market-level information (Frankel, Kothari, and Weber, 2006). Consistent with this view, we find that forecasts and recommendations are more optimistic for firms with higher firm-level information when VIX increases. In sum, our findings indicate that analysts' marginal benefit of optimistic output increases and its marginal cost decreases under higher market uncertainty.

Our main hypothesis is that the decrease in the marginal cost and the increase in the marginal benefit of issuing optimistic forecasts will lead to an increase in the level of optimistic output under higher market uncertainty. Consistent with our prediction, we find that an increase in market uncertainty increases analysts' optimistic forecast bias at the aggregate market level, the firm level, and the individual analyst level. We show that market uncertainty plays an important role in analysts' forecasts after controlling for well-known determinants of analysts' forecasting performance, such as experience, All-star status, brokerage size, coverage, firm size, etc. The effect of VIX on optimistic forecasts is economically and statistically significant: an increase in one standard deviation of the level of VIX is associated with a $13 \%$ increase in optimistic forecast relative to the average forecast error. ${ }^{5}$ We also find that stock recommendations become more optimistic when VIX is high. Analysts act more aggressively by issuing a higher percentage of buy recommendations for a given firm under high levels of $V I X$.

An alternative explanation for increased optimism is that when information uncertainty is high, analysts drop coverage if they have pessimistic information they decide not to disseminate

\footnotetext{
${ }^{5}$ Our findings are consistent with prior literature that examines the relationship between analysts' forecasts and firm-level uncertainty (Lim, 2001; Jackson, 2005). Jackson (2005) empirically tests how the conflicting incentives affect analyst output and finds that analyst optimism level increases with analyst-forecast dispersion, which is frequently used as a proxy for firm-level information uncertainty (Zhang, 2006).
} 
(McNichols and O’Brien, 1997). This self-selection of firms will lead to optimistic output. However, we observe that both the number of analysts covering a given firm and the earnings-forecast frequency increase with the level of VIX.

Another possible explanation for lower forecast accuracy under uncertainty is that analysts' forecasting ability declines when there is high market uncertainty. Making forecasts when market uncertainty is high is more challenging, since the analyst must understand macro-level data and analyze its direct effect on the firm, as well as its indirect effects through the firm's suppliers, customers, and competitors (Amiram, Landsman, Owens, and Stubben, 2014). Although this alternative explanation predicts that analysts' forecast accuracy declines under uncertainty, it does not explain the direction of the bias that we observe in our empirical analysis, i.e., the presence of optimistic bias (as opposed to pessimistic bias), nor can it explain why analysts become more aggressive in making stock recommendations.

This study contributes to the finance, accounting, and economics literature in several ways. Recent studies examine the effect of market uncertainty in financial markets on market liquidity (Chung and Chuwonganant, 2014), equity risk premium (Nagel, 2012; Graham and Harvey, 2013), and investor learning from new information (Loh and Stulz, 2015; Choi, 2015). However, the interaction between market conditions and analysts' forecasts has received comparatively little attention in the literature. A closely related paper is Amiram, Landsman, Owens, and Stubben (2014), which finds that analysts issue less timely and more inaccurate forecasts during periods of high market uncertainty. They use a behavioral explanation of analysts' underreaction to news in explaining forecast inaccuracy, while the current paper focuses on the direction of the forecast bias and directly examines the changes in analysts' incentives (i.e., by costs and benefits) in explaining the optimistic bias under market uncertainty. We find strong evidence that analysts' incentives vary with the level of market uncertainty, which is a novel finding. A related working paper by Loh and Stulz (2015) examines the role of analyst incentives in explaining why analysts have a greater impact during bad times (i.e., crises and recessions). Their research question is different from ours: They focus on explaining that analysts expend more effort during crises due to career concerns, while we 
explore reputational costs and trading-commission benefits to explain analysts' optimism during highmarket-uncertainty periods. Moreover, Loh and Stulz (2015) obtain mixed results on the estimated relationship between forecast accuracy and macroeconomic conditions, depending on their measure of forecast error. All three studies use different proxies for market uncertainty and macroeconomic conditions. ${ }^{6}$

Exploiting market uncertainty as the source of variation in studying analysts' incentives and output also adds novelty to our paper. The VIX index measures uncertainty related to the firm's market environment and thereby captures the degree of uncertainty all analysts face. Using an uncertainty measure exogenously determined outside analysts' reports can yield new insights into analysts' forecasts and incentives. ${ }^{7}$

Although sell-side analyst behavior has been examined extensively in the literature, there is mixed evidence on whether analysts provide valuable information and positively fulfill their role in the price-formation process (Dimson and Marsh, 1984; Womack, 1996) or opportunistically bias their output (O’Brien, 1988; Lys and Sohn, 1990; Brown, 1993). Periods of high market uncertainty are times when investors' demand for information is strong. Information generated by analysts is more valuable to investors at such times, as high-uncertainty periods are when investors are more uncertain about the state of the economy and the stock market, both of which affect individual firm performance. The findings of this study show that the increase in uncertainty in the information environment exacerbates the conflict of interest between analysts and investors: analysts face increased incentives to issue biased information just when investor demand for accurate information is at its highest.

Lastly, this study contributes to the economics literature on the importance of reputation formation. Fama (1980) shows that managers' reputational concerns help discipline the opportunistic

\footnotetext{
${ }^{6}$ Amiram, Landsman, Owens, and Stubben (2014) use market-return volatility as a measure for market uncertainty, whereas this study uses the VIX index (Bloom, 2009). Loh and Stulz (2015) use crises and recessions as a proxy for bad states of the economy. A discussion of various uncertainty proxies appears in section 3.1 .

${ }^{7}$ Prior studies use analysts' forecast dispersion as a measure for firm-level information uncertainty (Barron, Kim, Lim, and Stevens, 1998; Zhang, 2006).
} 
behavior of managers. ${ }^{8}$ Hong, Kubik, and Solomon (2000) show that performance affects career outcomes and thereby induces herding behaviors. This paper applies the basic insights from research on reputation effects to a sell-side analyst setting, by showing how the decrease in the expected reputation cost leads to more opportunistic behavior.

The rest of the paper is organized as follows. Section 2 includes the related literature and hypotheses development. Section 3 discusses the uncertainty proxies and describes the sample data and variables, and Section 4 describes the research design and reports the main empirical results. Section 5 includes additional tests for alternative explanations and extensions, and Section 6 includes robustness checks. Section 7 concludes.

\section{Related literature and hypotheses development}

\subsection{Prior literature and marginal cost-benefit framework}

There is a large body of literature on analysts' optimistic bias. ${ }^{9}$ One stream of the literature posits and finds supporting evidence for the notion that the higher trading commissions stimulated by optimistic output explain the optimistic bias (Hayes, 1998; Irvine, 2004; Jackson, 2005). Analysts are rewarded partly on the trading commissions they help to generate, as their bonuses are often tied to the commissions their recommendations generate for the brokerage firm (Irvine, 2004; Jackson, 2005; Cowen, Groysberg, and Healy, 2006). Such compensation schemes provide incentives for analysts to opportunistically promote trading activity. ${ }^{10}$ Other studies focus on analysts' incentives to maintain a favorable relationship with management, as firm management is an important source of private information (Francis and Philbrick, 1993; Das, Levine, and Sivaramakrishnan, 1998; Chen and Mastumoto, 2006, among others).

\footnotetext{
${ }^{8}$ See also Lazear and Rosen (1981) and Holmström (1999).

${ }^{9}$ An ample amount of evidence suggests that there is a systematic optimistic bias in analysts' earnings forecasts (Stickel, 1990; Abarbanell, 1991; Griffin and Tversky, 1992; Dreman and Berry, 1995; McNichols and O'Brien, 1997; Chopra, 1998; Lim, 2001; Hong and Kubik, 2003; Chen and Jiang, 2006; Cowen, Groysberg, and Healy, 2006, among others).

${ }^{10}$ In addition, analysts from brokerage houses that have underwriting relationships tend to issue more optimistic forecasts than analysts from nonaffiliated houses (see Dugar and Nathan, 1995; Lin and McNichols, 1998; Michaely and Womack, 1999; Dechow, Hutton, and Sloan, 2000).
} 
However, there is a cost for the opportunistic behavior of optimistic output. Analysts' forecast accuracy is an important factor in performance assessment, and poor forecast accuracy could lead to negative career outcomes (Hong, Kubik, and Solomon, 2000; Hong and Kubik, 2003). Since analysts interact with investors repeatedly, analysts' opportunistic behavior in generating optimistic output is constrained by their reputational and career concerns. Therefore, analysts face a tradeoff between the incentive to issue optimistically biased forecasts to generate more trade (or to maintain a favorable relationship with management) and the incentive to issue accurate forecasts to build a good reputation.

Given the costs and benefits of optimistic output that prior studies have shown, we develop three testable hypotheses related to the effect of market uncertainty on the changes in the marginal cost and benefit of analysts' optimistic output, and the level of analysts' optimistic output.

\subsection{Hypotheses development}

We adopt a simple utility-maximizing framework of marginal benefit and marginal cost to determine the analyst's choice on the level of optimistic output. In our framework, the optimal level of optimistic output is determined by the marginal cost and the marginal benefit of producing optimistic output that shifts by the level of market uncertainty.

We first consider reputational loss as the cost of producing optimistic output. Fama (1980) argues that reputation formation plays an important role in the labor market by disciplining the opportunistic behavior of managers. ${ }^{11}$ In a study more directly related to security analysts, Mikhail, Walther, and Willis (1999) show that poor relative performance leads to job turnover among security analysts. Hong, Kubik, and Solomon (2000) find that inaccurate earnings forecasts are penalized by termination and that such career concerns lead to herding with other analysts, especially for inexperienced analysts who have yet to establish their reputations. In sum, prior evidence shows that reputation matters for analysts when they issue earnings forecasts or stock recommendations.

\footnotetext{
${ }^{11}$ Reputation has also been applied to alleviating agency problems associated with sovereign debt (Eaton and Gersovitz, 1981), risky corporate debt (John and Nachman, 1985; Diamond, 1989), and outside equity (Gomes, 2000).
} 
Such reputational costs for issuing inaccurate forecasts vary with the changes in the information environment. For instance, Hong and Kubik (2003) find that analysts were less likely to be terminated for inaccurate forecasts during the stock-market boom of the early 2000s. When there is high uncertainty in the information environment, information signals contain more noise. In this case, analysts are less likely to be penalized for sending a biased signal to investors, since they can attribute the bias to noisy information signals. Therefore, the expected reputational loss of the analyst decreases under high market uncertainty. Following Hong, Kubik, and Solomon (2000), we expect that analysts are less likely to experience turnover when there is less reputational loss, and use analyst turnover as our proxy for the cost of producing optimistic output. Accordingly, we predict that analysts are less likely to experience turnover for optimistic forecasts when market uncertainty is high.

However, the marginal benefit of producing optimistic output can also change with the level of market uncertainty. Stimulating more trading activity, and thereby more trading commissions, is one important reason analysts tend to issue optimistically biased forecasts (Cowen, Groysberg, and Healy, 2006; Beyer and Guttman, 2011; Brown, Call, Clement, and Sharp, 2015). Jackson (2005) presents a dynamic game model of incomplete information, which implies that optimistic forecasts generate more trade than pessimistic forecasts under binding short-sale constraints. Hayes (1998) presents a model in which trading commission incentives affect analysts' production of inaccurate information to maximize trading volume. Her model shows that this effect is increasing with the level of investors' uncertainty about the individual stock's performance, which is likely to be higher during periods of high market uncertainty. When investors have high uncertainty about the firm's performance, their demand for information produced by analysts increases. In a similar vein, recent working papers directly show that new information has a greater effect on investors' beliefs under high market uncertainty (Amiram, Landsman, Owens, and Stubben, 2014; Choi, 2015; Loh and Stulz, 2015). These findings, combined with the prediction that optimistic forecasts generate more trading activity than pessimistic forecasts, lead us to hypothesize that analysts' incentives to issue optimistically biased output increase due to the increased marginal benefits from producing optimistic output under high market uncertainty. 
The marginal cost and benefit of producing optimistic output determines the analyst's choice on the level of optimistic output under different levels of market uncertainty, as illustrated in Figure 1. Let $M B_{0}$ and $M C_{0}$ represent the analyst's marginal benefit and marginal cost of issuing optimistically biased forecasts when uncertainty is low. The optimal amount of optimistic output when uncertainty is low is $O O_{0}$, where $M B_{0}=M C_{0}$. When market uncertainty is high, the marginal benefit curve and marginal cost curve of optimistic output shift to $M B_{l}$ and $M C_{l}$, and the analyst adjusts by choosing a new, higher level of optimistic output, $O O_{1}{ }^{12}$

Our framework leads to three testable hypotheses: We predict that analysts' optimistic output increases with the level of market uncertainty. The increase in analysts' optimistic output is explained by the decrease in marginal cost and the increase in marginal benefit of producing optimistic output. Therefore, we predict that the likelihood of analyst turnover in regards to optimistic output decreases with the level of market uncertainty. Our last prediction is that analysts' optimistic output is associated with more trading activity during periods of high market uncertainty than during periods of low market uncertainty.

\section{Market uncertainty measure, data and variables}

\subsection{Market uncertainty measure}

Not surprisingly, there is no single perfect measure of uncertainty, but a range of proxies like market volatility and forecast dispersion have been suggested (Bloom, 2009). We use the VIX index, which is the forward-looking 30-day implied volatility of stock options, as our measure of market uncertainty. The VIX index has been used in prior studies that examine the effect of market uncertainty in financial markets. Stock-market volatility is viewed as a market-based measure of economic uncertainty, and Bloom (2009) shows that stock-market volatility (VIX) is strongly correlated with firms' earning growth and industry productivity growth, as well as other real macroeconomic indicators.

\footnotetext{
${ }^{12}$ We do not assume that the marginal cost and the marginal benefit curves always shift simultaneously. The level of optimistic output can change from either one of the curve shifts as well.
}

This article is protected by copyright. All rights reserved. 
We are interested in VIX as a measure of market uncertainty that exogenously affects the information environment of all sell-side equity analysts. An increase in market uncertainty affects all analysts in gathering information about the effect of market-level factors on firm performance (Amiram, Landsman, Owens, and Stubben, 2014; Loh and Stulz, 2015). On the other hand, uncertainty measures used in previous studies, such as idiosyncratic volatility or analyst-forecast dispersion, are firm-level proxies that can be affected by confounding firm characteristics or analyst characteristics. These firm-level confounding factors vary across the cross-section of analysts and covered firms, whereas market uncertainty is common across all analysts and firms being covered. We believe that using VIX as opposed to firm-level uncertainty measures lessens the effects of the confounding unobservables that the firm-level uncertainty measures could carry. Using market-level uncertainty is also advantageous in establishing the link between uncertainty and the cost and benefit of optimistic output for each analyst. That is, because each analyst covers multiple firms, we can more accurately estimate the effect of uncertainty on the cost and benefit of optimistic output at the analyst level when exploiting cross-time variation than when exploiting cross-firm variation in uncertainty.

To verify that our market-level uncertainty measure, VIX, is a relevant variable for the analysts' information environment, we examine the relationship between VIX and analyst-forecast dispersion. In untabulated results, we find that the two measures are highly positively correlated, at both the aggregate market level and firm level. This indicates that VIX, as our measure of market uncertainty, is positively associated with the uncertainty in the analysts' information environment.

The remaining question about using VIX as our uncertainty measure is how it compares with other market-level uncertainty measures. Since VIX is a 30-day forward-looking measure of expected market volatility, we think that VIX is a more exogenous ex-ante measure than the ex-post marketreturn volatility used by Amiram, Landsman, Owens, and Stubben, 2014. Schwert (2011) and Bekaert and Hoerova (2014) examine the relationship between the VIX index and market-return volatility, and find that the two market-uncertainty proxies are highly correlated.

The VIX index can also reflect investor sentiment or risk aversion in addition to fundamental market volatility (Bekaert, Hoerova, and Lo Duca, 2013). It is often called the investors' "fear index" 
(Whaley, 2000). Our interest in using VIX is to capture the fundamental volatility in the market, but not the investor sentiment it could also carry. As a way to examine the effect of volatility and not the sentiment that is potentially contained in VIX, we also repeat our main analyses after controlling for the level of investor sentiment, using the measures by Baker and Wurgler (2006) and Baker, Bloom and Davis (2015), and we find results similar to our baseline results. In addition, if VIX captures mostly negative investor sentiment (or risk aversion), then it would be difficult to explain why analysts are more optimistic when investors are more pessimistic, when VIX is high.

Daily VIX data are from the Chicago Board Options Exchanges website. We construct VIX $X_{m t}$ by averaging the daily VIX data for month $m$ of year $t$. We use the average VIX at one month prior ( $m$ 1) to the analysts' forecast or recommendation announcement date. Using the contemporaneous VIX level in month $m$ yields materially similar results.

\subsection{Analyst-output measures}

Analysts' earnings forecasts, analysts' stock recommendations, firms' actual earnings, and earnings-announcement dates come from the Institutional Brokers Estimate System (IBES) annual update U.S. Detail History and Recommendations data sets. Using this source of data, we construct three variables of analyst output: analyst-forecast accuracy, stock recommendations, and stockrecommendation percentages.

We use annual earnings forecasts that are one-year-ahead forecasts. We use the unadjusted file to mitigate the rounding problem in IBES (see, for instance, Diether, Malloy, and Scherbina, 2002). Using split-adjustment factors from IBES, we adjust the unadjusted forecast so that it is on the same per-share basis as the unadjusted actual earnings. We examine four measures of analyst-forecast accuracy: the aggregate market-level forecast error, the firm-level consensus forecast error, the individual analyst-forecast error, and an optimistic forecast indicator variable. Analyst-level forecast error is denoted as $F E_{i j m t}$, which is the adjusted forecast error (analyst forecast minus actual earnings, scaled by the ending stock price in year $t-1$ ) of analyst $i$, firm $j$, month $m$, year $t .^{13}$ The consensus-

\footnotetext{
${ }^{13}$ The forecast-error variable $\left(F E_{i j m t}\right)$ is winsorized at the $1^{\text {st }}$ and the $99^{\text {th }}$ percentiles to reduce the impact of extreme outlier values of earnings surprises, as these values might be the result of measurement errors.
} 
forecast-error variable is the mean forecast error of all analysts issuing forecasts for firm $j$ in month $m$, year $t$. To compute the aggregate market-level measure of forecast error across all firms, we sum the consensus forecast error of all firms for each month $m$. Our fourth measure is an alternative unscaled measure of forecast bias, Optimistic Flag, which equals one if the analyst forecast is greater than the actual earnings. ${ }^{14}$ In some specifications, we include analyst $i$ 's forecast of firm $j$ only in the month closest to July (but not after July) in year $t$, as in Mikhail, Walther, and Willis (1999) and Hong and Kubik (2003), to mitigate econometric problems associated with high serial correlation between monthly analyst forecasts. ${ }^{15}$

As an alternative measure of analyst output, we examine stock recommendations at the individual analyst level and at the firm level. Individual analyst stock recommendations follow from the coded IBES text in reverse order to create a variable that increases with analyst optimism. $\operatorname{Recid}_{i j t}$ is the numeric value of the stock recommendations, where strong buy $=5$, buy $=4$, hold $=3$, underperform $=2$, and sell $=1$. To have a sample consistent with that of the earnings-forecast analysis, we include only stock recommendations issued by analysts who also issue earnings forecasts. We also limit our stock recommendations to those that are announced closest to July of year $t$, since recommendations are even more highly serially correlated than earnings forecasts (Hong and Kubik, 2003). Stock-recommendation percentages are also calculated as proportions of buy, sell, and hold recommendations for a stock $j$, in the month of July in year $t$. The resulting sample contains 240,891 individual analysts' earnings forecasts and 17,939 individual stock recommendations with non-

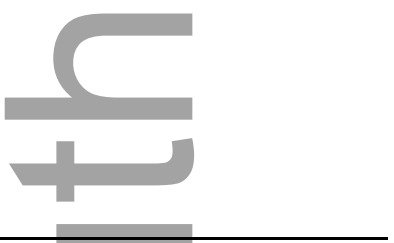

\footnotetext{
${ }^{14}$ One advantage of this variable is that it is unscaled. However, we do not use it as our main forecast-accuracy measure since an indicator variable drops information about the magnitude of the forecast error. In addition, we do not examine analysts' relative forecast accuracy (as in Hong, Kubik, and Solomon, 2000; Clarke, Khorana, Patel, and Raghavendra Rau, 2007) for our analysis on how market uncertainty affects analyst output, since we are interested in the effect of market uncertainty across all analysts.

${ }^{15}$ We include only firms with fiscal year ending in December to standardize the reporting period and make the forecasting horizon consistent across firms (Hong and Kubik, 2003). In addition, individual analysts' forecasts are not updated from month to month. Therefore, analysts' forecasts and recommendations exhibit high serial correlation across months throughout the year, which imposes econometric problems. Another advantage of examining mid-year forecasts is that we can separate out the effect of changes in optimism throughout the fiscal year (Richardson, Teoh, and Wysocki, 1999).
} 
missing analyst-characteristic variables. There are 18,092 stock-recommendation percentages. The sample period extends from 1996 to $2012 .^{16}$

\subsection{Analyst characteristics}

We consider the following analyst characteristics:Coverage ${ }_{i t}$, Experience $_{i t}$, Horizon $_{i j t}$, All - Star $_{i t}$, Boldness $_{i t}$, Rounding $_{i t}$, and Brokerage - Size $e_{i t}$. Coverage is the number of firms covered by analyst $i$ in year $t$. Experience is the natural logarithm of the number of years since analyst $i$ started issuing forecasts. ${ }^{17}$ Horizon is the natural logarithm of the number of days from the analyst's forecast-issue date to the actual earnings-announcement date for analyst $i$, firm $j$, month $m$, year $t$. AllStar is the indicator variable for the analyst $i$ identified as an All-star analyst by the All-American Institutional Investors magazine for year $t$. Boldness is the percentage of bold earnings forecasts issued by analyst $i$ in year $t$, where a forecast is defined as bold if the forecast is above both the analyst's prior forecast and the consensus forecast immediately before the forecast revision, or if the forecast is below both the analyst's prior forecast and the consensus forecast immediately before the forecast revision. Rounding is the percentage of rounded earnings forecasts issued by analyst $i$ in year $t$, where a forecast is rounded if it occurs at nickel intervals. Brokerage Size is the natural logarithm of the number of analysts employed by the brokerage firm of analyst $i$ for year $t$. These analystcharacteristic variables have been used as proxies for analysts' reputation and ability in prior studies (for example, see Clement, 1999; Clarke, Khorana, Patel, and Rau, 2007).

\subsection{Firm characteristics affecting analysts' output}

As Lim (2001) finds that forecast accuracy varies predictably as a function of firm size, we construct firm-characteristic variables as control variables from various data sets. Firm-level variables are obtained from Compustat Annual Updates, and institutional-holdings data are from the Thomson

\footnotetext{
${ }^{16}$ The sample size of individual stock recommendations is smaller than that of stock-recommendation percentages because we exclude analysts who do not issue earnings forecasts for that year, and because we drop observations with missing values for analyst-characteristic variables created from the earnings-forecast data. (When comparing the sample sizes between earnings forecast data and stock recommendations data in IBES, we see that the earnings forecast data sample is almost twice as large as the stock recommendation data sample.)

${ }^{17}$ We measure analyst experience from the starting year reported in IBES, and not from the starting year of our main sample period, to minimize the left-censored count of analyst experience.
} 
Reuters Spectrum database. We include firms that appear in all three data sets (IBES, CRSP and Compustat) in our analysis.

Firm size, denoted as $S I Z E_{j t}$ for firm $j$ in year $t$, is the $\log$ of market value of equity. The market-to-book ratio, denoted as Market/Book ${ }_{j t}$ for firm $j$ in year $t$, is calculated as the market value of the firm's equity at the end of the fiscal year plus the difference between the book value of the firm's assets and the book value of the firm's equity at the end of the year, divided by the book value of the firm's assets at the end of the year (Fich and Shivdasani, 2006). Size and market-to-book ratios also function as controls for firm-risk characteristics (Fama and French, 1992, 1993). Since the presence of institutional investors also affects the incentives of analysts and the information environment of the firm (see Ljungqvist, Marston, Starks, Wei, and Yan, 2006), we also control for the percentage of institutional investors. Spectrum collects quarterly data on stock holdings from the $13 \mathrm{~F}$ reports that institutions are required to file if their holdings exceed $\$ 100$ million. The holdings are aggregated over all institutions to arrive at the institutional-holdings number, and we construct the percentage of institutional investors (Institutional - Holdings $s_{j t}$ ) for firm $j$ in the last quarter of year $t$.

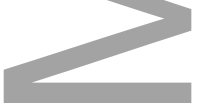

\subsection{Analyst turnover and performance Measures}

We construct two measures of analyst turnover. The first is a measure of the analyst leaving the industry, which we term "industry turnover" hereafter. To identify industry turnover, we look at whether the analyst issues earnings forecasts for any firm in the following year (Hong, Kubik, and Solomon, 2000). We assume that the analyst has left the industry in year $t$ if the analyst issued forecasts in the previous year $t-1$ but does not issue any forecasts in year $t$. Our turnover measure includes both voluntary and forced turnover, although forced turnover due to poor performance is more relevant to our hypothesis. However, voluntary turnover adds noise to our estimation of the 
relationship between job turnover, performance, and uncertainty, which should typically bias against finding a significant relationship. ${ }^{18}$

Our second measure of analyst turnover is a measure for the analyst moving to another brokerage firm in year $t$, which we term "job turnover" hereafter. Brokerages firms are sorted by size (i.e., the number of analysts) each year. The 10 largest brokerage firms each year are identified as high-status brokerage firms, while the rest are identified as low-status firms (Hong and Kubik, 2003). An analyst is identified as moving down (up) if the analyst worked for a high-status (low-status) brokerage firm in year $t-1$ and moves to a low-status (high-status) brokerage firm in year $t$. We assume that moving down proxies for the reputational cost of the analyst.

As our measure for analyst optimism that triggers industry turnover or job turnover, we construct a performance measure of relative optimism for each analyst, in the spirit of Hong, Kubik, and Solomon (2000). First, for each year $t$, firm $j$ that an analyst $i$ follows, we create a dummy variable that equals one if the analyst's forecast is greater than the consensus average forecast. The average of these dummy variables across the firms that the analyst covers yields an optimism score for analyst $i$ in year $t$. We then identify analysts with poor, biased performance by ranking the analysts' optimism scores by deciles for each year. An analyst is identified as most optimistic if the analyst falls into the highest decile for a given year. We create a dummy variable, Flag, which equals one if the analyst is ranked within the highest $10 \%$ of optimism scores in year $t-1$.

\subsection{Trading-activity measures}

Data on stock returns and trading volume are from the daily and monthly stock files of the Center for Research in Security Prices $(C R S P)$. We measure the effect of analyst optimism on trading activity by examining the abnormal trading volume around individual analysts' forecast or recommendation announcement dates. For analysts' earnings forecasts, we identify each analyst-

\footnotetext{
${ }^{18}$ Hong, Kubik, and Solomon (2000) support the idea that sell-side analysts are not likely to switch industries for a better job, noting that sell-side analysts, unlike buy-side analysts, are not likely to leave a job in the IBES sample to find a better job. Furthermore, in previous studies (Mikhail, Walther, and Willis, 1999; Groysberg, Healy, and Maber, 2011), analyst turnover is observed for analysts with low performance, rather than analysts with high performance. Mikhail, Walther, and Willis (1999) state that it is the worst-performing analysts who leave the analyst database.
} 
forecast-announcement date and measure the average trading volume around the analyst-forecastannouncement window of $[0,+1]$ days (in logs). We construct our abnormal-trading-activity measure as the difference between the average trading volume around the announcement window and expected trading volume (average trading volume 30 days prior to the analyst's announcement). We similarly measure abnormal trading volume around individual analysts' stock-recommendation-announcement dates as well.

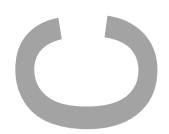

\section{Empirical results \\ 4.1 Descriptive statistics}

Table 1 presents sample descriptive statistics for the monthly VIX level, the analyst forecast error and stock recommendations, trading-activity variables, and analyst- and firm-characteristic variables. The summary statistics show that analysts' outputs are optimistic overall, and that they become more optimistic during high-market-uncertainty periods.

Forecast error is defined as the analysts' forecasts minus the actual earnings of the firm. If forecast error is positive, it means that the analysts' predictions are higher than actual earnings, so the forecast is optimistic. Consistent with prior research showing that analysts' reports are optimistically biased (O'Brien, 1988; Kang, O'Brien, and Sivaramakrishnan, 1994, among many others), Panel A shows that the mean forecast error is positive at 0.522 (scaled), although the median is zero. We find that the optimistic bias is also present in analysts' stock recommendations. The median individual analyst stock recommendation is a "buy." Similarly, the average percentage of buy recommendations is around 56\%. The percentage of sell recommendations is much lower than that of buy recommendations, with a mean value of around 5\%, which also shows a significant asymmetry in analysts' stock recommendations.

Panel B shows the comparisons of analysts' forecasts and recommendations between highand low-VIX periods. We find that the analyst-forecast error, optimistic flag, and analyst stock recommendations all are more optimistic during high-VIX periods. The differences in both the forecast error and stock recommendations are highly significant at the $1 \%$ significance level. 


\subsection{Analyst optimism and market uncertainty}

We first examine whether the level of analysts' optimism in earnings forecasts changes with the level of market uncertainty. Figure 2 illustrates a descriptive relationship between market uncertainty and analysts' optimism. The x-axis is the monthly VIX level, and the y-axis is the corresponding monthly aggregate forecast error (the sum of the consensus forecast error of all firms). The scatter plot, as well as a simple regression line between the two variables, shows a positive relationship between the VIX level and aggregate optimistic forecast error.

We next proceed to a multivariate analysis. In Panel A of Table 2, we examine the relationship between analysts' forecast error and VIX, controlling for analyst and firm characteristics, using equation (1).

$$
\begin{gathered}
F E_{i j m t} \\
=b_{0}+b_{1} \text { VIX }_{m-1(i j t)}+X_{i t-1} \alpha+\beta \text { Horizon }_{i j m t}+Y_{j t-1} \gamma+\theta_{j} \\
+\varepsilon_{i j t}
\end{gathered}
$$

where $i, j, m$ and $t$ index analyst, firm, month and year, respectively. In specification (1), the forecast error is measured at the aggregate market level; in specification (2), at the firm level; and in specification (3)-(5), at the individual analyst level. $X$ is the vector of analyst characteristics of coverage, experience, boldness, rounding, All-star status, and brokerage size in year $t$-1. Horizon denotes the forecasting horizon, which is the number of days between the analyst-forecast date and the forecast-period end date (in natural logrithm). $Y$ is the vector of firm characteristics of size, market-to-book ratio, and institutional holdings in year $t-1 . \theta_{j}$ denotes the vector of firm fixed effects. Standard errors are clustered by firm in specification (2), and by analyst and firm in specifications (3)(5). ${ }^{19}$ Our main coefficient of interest is $b_{1}$, which estimates the association between analyst-forecast error and market uncertainty. A positive $b_{1}$ indicates that analysts' forecasts are more optimistically biased when VIX increases, i.e., when there is a higher level of market uncertainty.

\footnotetext{
${ }^{19}$ Results are also robust to clustering by analyst in specifications (3)-(5).
} 
The results in Table 2, Panel A show that analysts do indeed tend to issue more optimistic forecasts when market uncertainty is high, regardless of the level of forecast error being measured. The coefficients for VIX are significantly positive in all specifications (1)-(5), indicating that optimistic forecast bias increases during high-uncertainty times. From specification (1), we find that there is a significantly positive relationship between VIX and the aggregate market-level forecast error each month. In specification (2), we observe that this relationship holds for the firm-level consensus forecasts as well. In specification (3), we also find consistent results when forecast error is measured at the individual analyst level. We are primarily interested in analyst-level data since it includes the most information on the individual analyst. The economic magnitude is large: in our main specification (3), a one-standard-deviation increase in the VIX level increases analysts' optimistic bias by $13 \%$ relative to the mean forecast error.

In specifications (4)-(5) of Table 2, Panel A, we examine an alternative unscaled measure of forecast error, which is the Optimistic Flag indicator variable. Optimistic Flag equals one if the analyst forecast is greater than the actual earnings (i.e., if the forecast is optimistic). We estimate the likelihood of an optimistic forecast using a linear probability model in specification (4), and a conditional logit model in specification (5). Our findings are consistent with prior specifications, and the signs and the magnitudes of the estimated coefficients are robust to our choice of the regressionmodel specification.

In specifications (2) - (5), we include only forecasts made in (or closest to) July, which is the mid-year of the firms' fiscal year ending in December. This is to address the concern that monthly forecasts are highly serially correlated (Hong and Kubik, 2003). Since our research focus is on individual analyst behavior, we examine the mid-year forecasts at the analyst level, with clustering standard errors by analyst and firm. ${ }^{20}$ This approach addresses the concern of serial correlation and preserves the information contained in the individual analyst-level data.

We control for analyst characteristics considered to be important covariates for analysts' forecasting performance in existing studies. In our main specification (3), we find, consistent with

\footnotetext{
${ }^{20}$ Untabulated estimation results are materially robust to including all months or only the mid-year month.
} 
past studies, that analysts' optimistic bias increases with analyst experience (Hong, Kubik, and Solomon, 2000), tendency to round forecasts (Herrmann and Thomas, 2005), and brokerage size (Clement and Tse, 2005). Meanwhile, optimistic output decreases with the number of firms the analyst covers and the percentage of bold forecasts. We also observe that forecasts are more optimistic when forecasts are made earlier in the year. ${ }^{21}$

When looking at the coefficients of the firm-characteristic variables, we find that forecasts are more optimistic for firms with low market-to-book ratios and firms with fewer institutional investors. ${ }^{22} \mathrm{We}$ also observe a positive association between forecast optimism and firm size. One possible explanation is that because larger trades can be executed for larger firms, the incentive to issue optimistic forecasts for larger trading commissions is stronger for larger firms. These findings imply the presence of the cost and benefits of optimism when analysts issue forecasts, which is consistent with our incentive-based cost-benefit framework of analyst optimism.

In Panel B, we examine the effect of market uncertainty on analyst-forecast error across different forecasting horizons. We categorize analyst forecasts into four groups based on the number of days from the forecast-announcement date to the forecast-period end date: [0-60], [61-180], [181270], and [271-360] days. The effect of VIX on individual analyst-forecast error is significant and positive throughout all short and long forecasting horizons. Consistent with prior literature, we find that analysts issue more optimistic forecasts under high market uncertainty, earlier in the year. The magnitude of the VIX coefficient of the longest horizon ([271-360] days) is more than twice that of other forecasting horizons.

Lastly, we find that results for the post-Regulation FD period (after October, 2000) are very similar to those for the whole sample period in Panel A. The findings suggest that Regulation FD did not significantly change analysts' incentives to issue optimistic forecasts, as suggested by recent

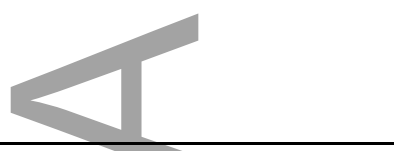

\footnotetext{
${ }^{21}$ This is consistent with prior studies, which show that analysts tend to give more optimistic reports in the beginning of the year and then revise their estimates downward as the earnings-announcement dates approach at the end of the year (Ackert and Athanassakos, 1997; Richardson, Teoh, and Wysocki, 1999; Ke and Yu, 2006).

${ }^{22}$ Our finding that growth firms (those with high Market/Book) tend to have lower forecast error than value firms is consistent with Dechow and You (2012).
} 
survey studies (Brown, Call, Clement, and Sharp, 2015). ${ }^{23}$ In sum, we find a significant positive effect of market uncertainty on analysts' optimistic earnings forecasts throughout various specifications. The overall evidence supports our hypothesis that analysts' optimism increases with market uncertainty.

\subsection{Stock recommendations and market uncertainty}

We next examine an alternative output of analysts, stock recommendations. One advantage of analyzing stock recommendations is that stock recommendations are summaries of analysts' opinions about a firm that incorporate all of the information analysts possess, and are not based solely on information related to the firm's next-period earnings. Therefore, stock recommendations provide a directly comparable measure of analysts' opinions across different market-uncertainty levels. Since high-uncertainty periods tend to be highly correlated with recessionary periods, firms might experience more difficulty in meeting analysts' expectations during bad times. Stock recommendations do not suffer from the issue of firms' actual earnings not meeting analysts' expectations, as they are independent of the firms' actual performance. Stock recommendations are also independent of managerial incentives to meet or beat analysts' earnings forecasts.

We examine whether stock recommendations change with level of market uncertainty in Table 3. In Table 3, Panel A, we examine the relationship between individual analyst stock recommendations and VIX, using equation (1) by replacing forecast error with $\operatorname{Recid}_{i j t}$. The dependent variable, Recid, is a numeric variable that translates the recommendation text of analyst $i$ for firm $j$ in the month closest to July of year $t$ into numeric values. A larger Recid value indicates a more optimistic view of the firm. We find that the coefficient of VIX is significantly positive in specifications (1)-(2), which indicates that analysts have more optimistic recommendations when market uncertainty is high. This optimism remains after the Global Settlement (untabulated). ${ }^{24}$

\footnotetext{
${ }^{23}$ The findings (untabulated) are available from the authors. Our results are also robust to excluding the financial crisis period, which was a period of extreme uncertainty (untabulated).

${ }^{24}$ The number of observations between specifications (1) and (2) differ since there are analysts who issue earnings forecasts but not stock recommendations and the control variables are constructed from earnings forecast data.
} 
In Table 3, Panel B, we use the percentage of stock recommendations as the dependent variable. The dependent variable is the buy-, sell-, or hold-recommendation percentage of a stock. Equation (2) shows the empirical model with the buy-recommendation percentage of a stock, $B u y P c t_{j t}$, as the dependent variable. BuyPct ${ }_{j t}$ is the buy-recommendation percentage of firm $j$ in July of year $t$. VIX is the monthly average VIX level in June.

$$
\text { BuyPct }_{j t}=b_{0}+b_{1} V I X_{m-1(t)}+Y_{j t-1} \beta+\theta_{j}+\epsilon_{j t}
$$

As in equation (1), $j$ is the firm index, and $t$ is the year index. Other firm characteristics control variables are size, market-to-book ratio, and institutional holdings, collectively denoted as $Y$. The term $\theta_{j}$ denotes the vector for firm fixed effects.

Table 3, Panel B shows that only the percentage of buy recommendations increases when market uncertainty increases. In specification (1), the dependent variable is the percentage of buy recommendations $\left(B u y P c t_{j t}\right)$. The coefficient of VIX in specification (1) is highly positive and significant, whereas it is significantly negative or insignificant for sell or hold recommendations in specifications (2)-(3). A one-standard-deviation increase in the level of VIX is associated with an increase of $3.21 \%$ in buy recommendations, while sell and hold recommendation percentages decrease by $1.14 \%$ and $2.09 \%$, respectively. We find that stock recommendations remain optimistic under higher uncertainty even after the Global Settlement (untabulated).

In sum, we find strong evidence of an increased level of analyst optimism under higher market uncertainty, in both earnings forecasts and stock recommendations. We next explore possible explanations for the changes in analyst optimism in the following two sections, under our analyst utility-maximization framework.

\subsection{Reputation, optimism, and uncertainty}

If inaecurate forecasts serve as a signal for inferior forecasting ability, then we expect analysts' reputation to decrease if they issue optimistic forecasts. However, we expect analysts' reputation to suffer less from inaccurate biased forecasts when there is high market uncertainty, as discussed in section 2. We use analysts' turnover measures as proxies for reputational cost. Our measures of 
turnover are the event of leaving the industry ("industry turnover") and the event of moving from one brokerage firm to another ("job turnover"), as discussed in section 3. We predict that analysts are less likely to experience industry turnover or move to smaller brokerage firms under high market uncertainty. We test this hypothesis by examining whether poor prior forecasting performance (defined by the analyst performance measure Flag, as discussed in section 3) is associated with a lower likelihood of future turnover when VIX is high, controlling for analyst attributes that have been shown to affect turnover in the literature:

$$
\begin{gathered}
\text { Turnover }_{i t} \\
=b_{0}+b_{1} \text { VIX }_{t-1}+b_{2} \text { Flag }_{i t-1}+b_{3} \text { Flag }_{i t-1} * \text { VIX }_{t-1}+X_{i t-1} \alpha+\varepsilon_{i t}
\end{gathered}
$$

Equation (3) is estimated by a logit probability model with robust standard errors, and the estimation results are reported in Table 4. In Panel A, the dependent variable Turnover Tit $_{\text {in }}$ is binary variable that equals one if analyst $i$ leaves the industry in year $t$. In Panel $\mathrm{B}$, the dependent variable is MoveDown $_{i t}\left(\right.$ Move Up $\left.p_{i t}\right)$, which equals one if analyst $i$ changes from a high-status firm to a low-status firm (from a low-status firm to a high-status firm) in year $t \cdot{ }^{25}$ VIX is averaged at the annual level (scaled by 1/100) since Flag is at the annual level, and we are interested in the coefficient of their interaction term. $X$ denotes the vector of analyst-characteristic variables of coverage, experience, boldness, rounding, All-star status, and brokerage size. The coefficient of interest is $b_{3}$ in equation (3). We predict $b_{3}$ to be negative, which means that the most optimistically biased analysts are less likely to experience turnover when market uncertainty is high.

The $b_{3}$ coefficient estimates reported in Table 4, Panel A are in accord with our predictions. The interaction of Flag and VIX is significantly negative, which shows that the likelihood of industry turnover for an analyst in the highest $10 \%$ of optimism is lower under high market uncertainty. The relation between VIX and industry turnover is also economically meaningful. In specification (4), a one-standard-deviation increase in VIX leads to a $7 \%$ decrease in the probability of industry turnover (relative to the mean value) when the analyst is the most optimistic.

\footnotetext{
${ }^{25}$ The Move Down dummy variable equals one when the analyst leaves the industry as well. All results are robust to the exclusion of industry turnover. We exclude analysts with less than three years of experience, as in Hong and Kubik (2003).
}

This article is protected by copyright. All rights reserved. 
The findings in Panel B regarding analysts' job turnover under market uncertainty are also consistent with those in Panel A. The interaction of Flag and VIX is significantly negative when the dependent variable is the Move Down dummy variable (specifications (1)-(3)), while it is positive but insignificant when the dependent variable is the Move Up dummy variable (specifications (4)-(6)). This finding indicates that the likelihood of an optimistic analyst moving down in brokerage-firm status decreases when market uncertainty is high.

In sum, we find that analysts' career outcomes also vary with market uncertainty and that analysts' reputational costs decrease with the level of market uncertainty.

\subsection{Trading aetivity, analysts' optimism, and uncertainty}

We next explore the effect of analysts' optimism on trading activity under different levels of market uncertainty. We focus on the trading activity around analyst-announcement dates. As in section 2, we predict that optimistic output has a stronger effect on investors' beliefs, and hence on trading activity, when market uncertainty is high. Therefore, we are primarily interested in the interaction term between analyst-earnings-forecast error (or stock recommendations) and the VIX index when the dependent variable is trading volume. The dependent variable, $A V o l_{i j t}$, is the average abnormal trading volume of firm $j$ around the forecast (recommendation) announcement window ([0, +1 days]) of analyst $i$ in (or closest to but not after) July of year $t$ (in natural logarithm). Abnormal trading volume is the difference between trading volume and expected trading volume (average trading volume 30 days prior to the analyst's announcement).

$$
\begin{gathered}
A V o l_{i j t}=b_{0}+b_{1} V I X_{m-1(i j t)}+b_{2} F E_{i j t}+b_{3} F E_{i j t} * V I X_{m-1(i j t)}+\text { BHorizon }_{i j t} \\
+X_{i t-1} \gamma+Y_{j t-1} \phi+\theta_{j}
\end{gathered}
$$

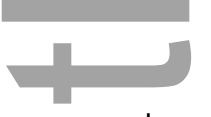

As in equation (1), $i, j, m$, and $t$ index analyst, firm, month and year, respectively. $V I X$ is the average monthly VIX level, one month prior to the analyst announcement date. Horizon denotes the forecasts horizon. $X$ denotes the vector of analyst characteristics of coverage, experience, All-star status, boldness, rounding, and brokerage size. $Y$ denotes the vector of firm characteristics of size, market-to-book ratio, and institutional holdings. $\theta_{j}$ denotes the vector of firm fixed effects. Standard 
errors are clustered by analyst and firm. The coefficient of interest is $b_{3}$. Since $F E_{i j t}$ is positive for optimistic forecasts, a positive $b_{3}$ coefficient indicates that optimistic forecasts during highuncertainty times lead to more trading activity.

The results in Table 5, Panel A show that analyst optimism is indeed associated with more trading activity when market uncertainty is high. ${ }^{26}$ The coefficient of the interaction term between forecast error and VIX is significantly positive in all specifications. This relationship between optimism, uncertainty, and trading activity is significant, even after we control for various analyst and firm characteristics. ${ }^{27,28}$

In Table 5, Panel B, we repeat the analysis in Panel A by looking at the effect of optimistic stock recommendations on trading activity. We repeat equation (4) after replacing the forecast-error term $\left(F E_{i j t}\right)$ with the numeric value of the stock-recommendations term $\left(\operatorname{Recid}_{i j t}\right)$. We find that the interaction term between individual stock recommendations and VIX is significantly positive, which indicates that optimistic recommendations are associated with increased trading activity under high uncertainty. $^{29}$

Our empirical findings show that the marginal benefit and marginal cost of issuing optimistic output change with the level of market uncertainty. We find that analysts' reputational costs of issuing optimistic output are lower while the benefits of optimistic output are larger when the level of market uncertainty is high. These results are consistent with the three incentive-based predictions on the positive relationship between optimistic output and market uncertainty.

\section{Extensions}

\subsection{Relationship with firm management}

\footnotetext{
${ }^{26}$ We suppress the eoefficient estimates of the control variables in Table 6 for brevity.

${ }^{27}$ We find robust results when examining the post-Regulation FD period.

${ }^{28}$ While further study is required to understand why only optimistic views have a stronger impact on investors' trading activity under high uncertainty than under low uncertainty, one possible explanation is that short-sale constraints are more binding when uncertainty is high. Under short-sale constraints, pessimistic trading activity is limited while optimistic trading activity is not (Jackson, 2005). We do not formally test this explanation since it is beyond the scope of our paper.

${ }^{29}$ At the firm level, we also find that a higher percentage of buy recommendations is associated with more trading volume when VIX is high, while sell and hold recommendations are not (untabulated).
} 
Another important benefit of issuing optimistic output is maintaining a favorable relationship with firm management (Francis and Philbrick, 1993; Das, Levine, and Sivaramakrishnan, 1998; Lim, 2001; Chen and Matsumoto, 2006; Ke and Yu, 2006; Mayew, 2008; Soltes, 2014). The literature has shown that the benefits of maintaining a good relationship with firm management are larger for analysts who cover firms with earnings that are difficult to forecast. Brown, Call, Clement, and Sharp (2015) find that gaining private information from inside management remains important even after the passage of Regulation FD. In this section, we examine how this alternative benefit of optimistic output changes when market uncertainty changes. We posit that the demand for information from firm management is stronger for firms with more firm-level than market-level information. The higher the correlation between the firm and market return, the larger the market component of the firm's return and the smaller the effect of firm-specific information on the firm's return (Bhushan, 1989). Following Frankel, Kothari, and Weber (2006), we measure the degree of firm-level information by calculating the correlation between the firm and market return, and use it as a proxy for the importance of maintaining a favorable relationship with firm management. A firm has a high (low) degree of market-level (firm-level) information if the $R^{2}$ from firm $j$ 's market-model regression in year $t$ is high. $R S Q$ is the variable name that corresponds to the $R^{2}$ from the market model.

We then examine the interaction effect of VIX and $R S Q$ on analyst output to test whether analysts yield more optimistic output for firms with less market-level information during high-VIX times. We expect that when VIX increases, gaining private information from management becomes more important for firms with low $R S Q$. Therefore, we expect a negative relationship between the $R S Q^{*} V I X$ interaction term and analyst output.

The results are reported in Table 6, specifications (1)-(4). The dependent variable is the individual analyst-earnings-forecast error $(F E)$ in specifications (1)-(2), and stock recommendations (Recid) in specifications (3)-(4). Consistent with the findings in Tables 3 and 4, the coefficient of VIX is positive and statistically significant in specifications (1)-(4), which indicates that analysts issue optimistically biased output when market uncertainty is high. The coefficient of interest is $R S Q^{*} V I X$, which is significantly negative throughout most specifications (with the exception of stock 
recommendations after the Global Settlement). Since firms with more firm-level information are firms with low $R S Q$, a negative coefficient implies that analysts issue more optimistic output for firms with higher firm-level information when market uncertainty increases. The findings suggest that the benefit of issuing optimistically biased output is stronger for firms with relatively more firm-level information. We find that access to management remains an important incentive for optimistic output during periods of high uncertainty, in particular. ${ }^{30}$ Overall, we find relationship with firm management to be another important benefit of analyst optimism, especially during periods of high market uncertainty

\subsection{Analyst experience, optimism, and uncertainty}

Hong, Kubik, and Solomon (2000) find that analysts' experience is an important factor in the consequence of analyst output and performance on analyst reputation. In this section, we explore whether analysts' prior experience affects their level of optimism under market uncertainty. Our incentive-based hypotheses of analyst optimism predict that the optimism level increases when the reputational cost of optimistic output is lower. Hong, Kubik, and Solomon (2000) find that inexperienced analysts, who have yet to establish their reputation, are more likely to experience negative career outcomes following poor performance than experienced analysts. Accordingly, we expect that increased market uncertainty would downwardly shift the marginal cost of optimistic output further for inexperienced analysts. We therefore exploit the difference in analysts' experience level to compare the relative magnitude of the marginal cost changes across analysts, and explore how this affects the changes in optimism.

To test whether analysts' optimism under market uncertainty depends on analysts' prior experience, we construct an indicator variable, INEXP, which equals one if the analyst has experience below the median value of eight years in our sample. In Table 6, specifications (5)-(8), we compare forecast errors and stock recommendations between the above-median- and below-median-experience

\footnotetext{
${ }^{30}$ In untabulated tables, we find that incentive to maintain a good relationship with management did not change after the passage of Regulation FD, which is consistent with the recent survey work by Brown, Call, Clement, and Sharp (2015). In contrast, we find that the benefits associated with firm management decreased after the Global Settlement for stock recommendations.
} 
analysts. Specifications (5)-(6) compare the forecast errors. We observe that analysts with less experience issue more optimistic forecasts when market uncertainty increases. The coefficient of $I N E X P^{*} V I X$ is positively significant. Specifications (7)-(8) compare stock recommendations, and we find that the difference across the analyst experience groups in the effect of VIX on recommendation output is also positive, although statistically insignificant.

From Table 6, specifications (5)-(6), we find that analysts' experience matters for issuing optimistic forecasts under high market uncertainty. Next, in Table 7 , we test whether such an asymmetric result can be attributed to a greater shift in the marginal cost curve for inexperienced analysts. We repeat the analysis in Table 4 separately for the above- and below-median experience groups. Observing the interaction term between Flag and VIX, we find that compared to experienced analysts, inexperienced analysts are less likely to be penalized for issuing optimistically biased forecasts under high market uncertainty. The decrease in the likelihood of industry turnover (or moving down to low-status brokerage firms) due to optimistic output under high uncertainty is larger for inexperienced analysts. The evidence in Table 7 indicates that the effect of market uncertainty on analyst optimism differs across the cross-section of analysts, based on their prior experience.

\section{Robustness tests}

\subsection{Investor sentiment and analyst optimism}

To ensure that our findings are not driven by the investor sentiment effect that is potentially contained in the VIX index, we repeat our main analyses on analyst optimism, after controlling for investor sentiment using two measures developed in past studies: the Baker and Wurgler (2006) investor sentiment index and the Baker, Bloom, and Davis (2015) economic policy uncertainty index. In untabulated results, we find that the VIX coefficient remains significantly positive after we control for investor sentiment. Thus, we conclude that our findings are driven by the fundamental volatility that is captured in the VIX index, rather than the investor sentiment that the VIX index may incorporate.

\subsection{Analysts' self-selection under uncertainty}

This article is protected by copyright. All rights reserved. 
McNichols and O'Brien (1997) were the first to show self-selection in analyst coverage. They find that analysts with sufficiently low private estimates might decide to drop coverage due to economic incentives. If analysts give pessimistic recommendations, firms are likely to withhold inside information from these analysts; therefore, analysts prefer to focus on stocks for which they can issue a "strong buy" or "buy" recommendation. The missing negative opinions introduce an optimistic bias to the mean reported forecast. The positive relationship between optimistic output and uncertainty may be explained by this selection of firms being covered, as the analysts' private estimates are likely to be low in high-uncertainty times.

However, we do not find that analysts drop coverage during high-uncertainty times. In Table 8, specifications (1)-(2), we regress the number of analysts issuing earnings forecasts or stock recommendations on market uncertainty. We find that both the number of analysts issuing earnings forecasts and the number of analysts issuing stock recommendations increase with the VIX level for a given firm. Our findings show that this alternative explanation cannot explain analyst optimism under market uncertainty.

\subsection{Analyst-forecast frequency and timeliness}

Increased optimism may also be explained by analysts producing less information (and only favorable information) when there is much noise in the information environment. Jacob, Lys, and Neale (1999) find that analysts' forecast frequency proxies for analysts' effort and the amount of information produced by analysts. We thus compare analysts' forecast frequency across different levels of uncertainty in Table 8, specifications (3)-(4). The dependent variables are measures of the number of forecasts issued. In specification (3), the dependent variable is the natural logarithm of the total number of forecasts issued by analyst $i$ in year $t$. In specification (4), the dependent variable is the natural logarithm of the average number of forecasts issued by analyst $i$ per firm $j$ covered in year $t$. The results show that analysts issue forecast revisions more frequently and put in more effort when uncertainty is high, which is evidence against the informational story that analysts produce less information when they have less accurate information. 
Another alternative explanation for the positive relationship between optimistic output and market uncertainty is that analysts try to be more timely at the cost of being less accurate in highmarket-uncertainty times. Analysts generally trade off timeline and accuracy, as forecasts issued later in the year are likely to include more information and provide a more accurate forecast (Ramnath, Rock, and Shane, 2008). If investors' demand for information increases with uncertainty, it could be that analysts issue timelier forecasts to meet investors' demands, which could lead to less accurate, and perhaps more optimistic output (given that analyst outputs are optimistic rather than pessimistic in general). However, Amiram, Landsman, Owens, and Stubben (2014) find that analysts' forecasts are less timely when market uncertainty is high, which is inconsistent with the above alternative explanation.

We find that the overall evidence is consistent with our incentive-based hypothesis that analysts issue more optimistic forecasts during high-uncertainty times, due to decreased marginal costs and increased marginal benefits. We do not find evidence that supports the alternative explanations.

\section{Conclusion}

The performance and incentives of analysts have important implications for studies on capital markets. This research investigates the properties of analysts' forecasts and decision-making processes by examining the effect of market uncertainty on analysts' output. We show that market uncertainty is an important factor that affects analysts' forecasts and recommendations. We find that analyst optimism increases with the level of market uncertainty. We also find that market uncertainty affects the consequences of analyst optimism. Analysts' reputation loss is less severe, as highuncertainty times are when the information environment is noisy. On the other hand, their trading commissions increase with the increased trading activity that follows optimistic output. Our findings suggest that the tradeoff decision that analysts make between reputation building and generating trading commissions varies across time. 
The findings on time-varying analyst optimism add to the prior literature on static analystforecast incentives and trading activity (Hayes, 1998; Jackson, 2005; Beyer and Guttman, 2011). This paper also complements studies that examine the relationship between firm-level uncertainty and analysts' forecasts and its effect on prices (Imhoff and Lobo, 1992; Ackert and Athanassakos, 1997; Zhang, 2006) by exploiting an alternative exogenous measure of uncertainty. Using a market-level uncertainty measure of the information environment, we are able to circumvent the potential endogeneity in firm-level uncertainty measures in explaining analysts' output.

Finally, it is noteworthy that analysts' biased output has a stronger impact on trading activity in high-uncertainty periods, since high-uncertainty periods are when investor demand for information is at its highest. We find that investors are not receiving more accurate information or recommendations from analysts in these periods. Increased analyst optimism in times of high market uncertainty suggests that there is a greater conflict of interest between analysts and investors when the demand for information is high. Investors should account for analysts' time-varying optimistic forecasts and recommendations, since optimistic biases have a direct effect on firm valuation and hence on investors' wealth.

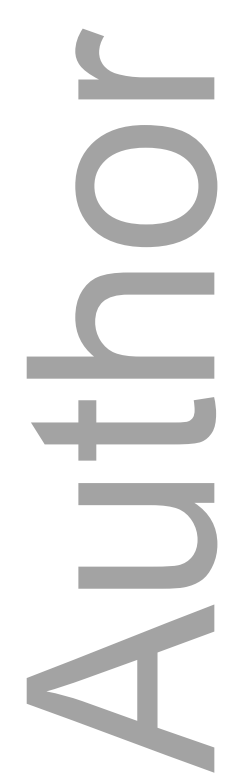




\section{References}

Abarbanell, J., 1991. Do analysts' earnings forecasts incorporate information in prior stock price changes? Journal of Accounting and Economics 14, 147-165.

Ackert, L. F. and G. Athanassakos, 1997. Prior uncertainty, analyst bias and subsequent abnormal returns, Journal of Financial Research 20(2), 263-273.

Amiram, Landsman, Owens and Stubben, 2014. Analysts' forecasts during periods of high market uncertainty. Working paper, Columbia Business School.

Baker, S. R., Bloom, N. and Davis, S. J., 2015. Measuring economic policy uncertainty (No. w21633). Working paper, National Bureau of Economic Research.

Baker, M. and J. Wurgler, 2006. Investor sentiment and the cross-section of stock returns, The Journal of Finance 61(4), 1645-1680.

Barron, O. E., O. Kim, S. Lim and D. E. Stevens, 1998. Using analysts' forecasts to measure properties of analysts' information environment, The Accounting Review 73, 421-433.

Bekaert, G. and M. Hoerova, 2014. The VIX, the variance premium, and stock market volatility, Journal of Econometrics 183, 181-192.

Bekaert, G., M. Hoerova and M. Lo Duca, 2013. Risk, uncertainty and monetary policy, Journal of Monetary Economics 60(7), 771-788.

Beyer, A. and I. Guttman, 2011. The effect of trading volume on analysts' forecast bias, The Accounting Review 86, 451-481.

Bhushan, R., 1989. Firm characteristics and analyst following, Journal of Accounting and Economics $11,255-274$.

Bloom, N., 2009. The impact of uncertainty shocks, Econometrica 77, 623-685.

Bradshaw, M. T., 2011. Analysts' forecasts: What do we know after decades of work? SSRN Working Paper, 1880339.

Brown, P., 1993. Comments on 'Earnings forecasting research: Its implications for capital markets research,' by L. Brown, International Journal of Forecasting 9, 331- 335.

Brown, L. D., A. C. Call, M. B. Clement and N. Y. Sharp, 2015. Inside the "black box" of sell-side financial analysts, Journal of Accounting Research 53(1), 1-47.

Chen, Q. and W. Jiang, 2006. Analysts' weighting of private and public information, Review of Financial Studies 19, 319-355.

Chen, S. and D. A. Matsumoto, 2006. Favorable versus unfavorable recommendations: The impact on analyst access to management-provided information, Journal of Accounting Research 44(4), 657-689.

Choi, H., 2015. A tale of two uncertainties. Working paper, Loyola University Chicago.

Chopra, V. K., 1998. Why so much error in analysts' earnings forecasts? Financial Analysts Journal $54,30-37$.

Chung, K. H. and C. Chuwonganant, 2014. Uncertainty, market structure, and liquidity, Journal of Financial Economics 113(3), 476-499. 
Clarke, J., A. Khorana, A. Patel and P. Raghavendra Rau, 2007. The impact of All-star analyst job changes on their coverage choices and investment banking deal flow, Journal of Financial Economics 84(3), 713-737.

Clement, M. B., 1999. Analyst forecast accuracy: Do ability, resources, and portfolio complexity matter? Journal of Accounting and Economics 27(3), 285-303.

Clement, M. B. and S. Y. Tse, 2005. Financial analyst characteristics and herding behavior in forecasting, The Journal of Finance 60(1), 307-341.

Cowen, A., B. Groysberg and P. Healy, 2006. Which types of analyst firms are more optimistic? Journal of Accounting and Economics 41, 119-146.

Das, S., C. Levine and K. Sivaramakrishnan, 1998. Earnings predictability and bias in analysts' earnings forecasts, The Accounting Review 73, 277-294.

Dechow, P. M., A. P. Hutton and R. G. Sloan, 2000. The relation between analysts' forecasts of longterm earnings growth and stock price performance following equity offerings, Contemporary Accounting Research 17(1), 1-32.

Dechow, P. and H. You, 2012. Analysts' motives for rounding EPS forecasts, The Accounting Review 87, 1939-1966.

Diamond, D., 1989. Reputation acquisition in debt markets, Journal of Political Economy 97, 828862 .

Diether, K. B., C. J. Malloy and A. Scherbina, 2002. Differences of opinion and the cross section of stock returns, The Journal of Finance 57(5), 2113-2141.

Dimson, E. and P. Marsh, 1984. An analysis of brokers' and analysts' unpublished forecasts of UK stock returns, The Journal of Finance 39(5), 1257-1292.

Dreman, D. and M. Berry, 1995. Analyst forecasting errors and their implications for security analysis, Financial Analysts Journal 51, 30-42.

Dugar, A. and S. Nathan, 1995. The effect of investment banking relationships on financial analysts' earnings forecasts and investment recommendations, Contemporary Accounting Research 12(1), 131-160.

Eaton, J. and M. Gersovitz, 1981. Debt with potential repudiation: Theoretical and empirical analysis, The Review of Economic Studies 289-309.

Fama, E. F, 1980. Agency problems and the theory of the firm, Journal of Political Economy 88, 288-307.

Fama, E. F. and K. R. French, 1992. The cross section of expected stock returns, Journal of Finance $46,427-466$.

Fama, E. F. and K. R. French, 1993. Common risk factors in the returns on stocks and bonds, Journal of Financial Economics 33, 3-56.

Fich, E. and A. Shivdasani, 2006. Are busy boards effective monitors? Journal of Finance 61, 689724.

Francis, J. and D. Philbrick, 1993. Analysts' decisions as products of a multi-task environment, Journal of Accounting Research 31, 216-230. 
Frankel, R., S. P. Kothari and J. Weber, 2006. Determinants of the informativeness of analyst research, Journal of Accounting and Economics 41, 29-54.

Gomes, A., 2000. Going public without governance: Managerial reputation effects, Journal of Finance 55, 615-646.

Graham, J. R. and C. R. Harvey, 2013. The equity risk premium in 2013, SSRN Working Paper, 2206538.

Griffin, D. and A. Tversky, 1992. The weighing of evidence and determinants of confidence, Cognitive Psychology 24, 411-435.

Groysberg, B., P. M. Healy and D. A. Maber, 2011. What drives sell-side analyst compensation at high-status investment banks? Journal of Accounting Research 49(4), 969-1000.

Hayes, R. M,, 1998. The impact of trading commission incentives on analysts' stock coverage decisions and earnings forecasts, Journal of Accounting Research 36, 229-320.

Herrmann, D. and W. B. Thomas, 2005. Rounding of analyst forecasts, The Accounting Review 80(2), $805-823$.

Holmström, B., 1999. Managerial incentive problems: A dynamic perspective, The Review of Economic Studies 66(1), 169-182.

Hong, H. and J. D. Kubik, 2003. Analyzing the analysts: Career concerns and biased earnings forecasts, Journal of Finance 58, 313-351.

Hong, H., J. D. Kubik and A. Solomon, 2000. Security analysts' career concerns and the herding of earnings forecasts, RAND Journal of Economics 31, 121-144.

Imhoff, E. and G. Lobo, 1992. The effect of ex-ante earnings uncertainty on earnings response coefficients, The Accounting Review 67, 427-439.

Irvine, P. 2004, Analysts' forecasts and brokerage-firm trading, The Accounting Review 79, 125-149.

Jackson, A., 2005. Trade generation, reputation and sell-side analysts, Journal of Finance 60, 673717.

Jacob, J., T. Z. Lys and M. A. Neale, 1999. Expertise in forecasting performance of security analysts, Journal of Accounting and Economics 28(1), 51-82.

John, K. and D. C. Nachman, 1985. Risky debt, investment incentives, and reputation in a sequential equilibrium, The Journal of Finance 40(3), 863-878.

Kang, S., J. O'Brien and K. Sivaramakrishnan, 1994. Analysts' interim earnings forecasts: Evidence on the forecasting process, Journal of Accounting Research 32(1), 103-112.

$\mathrm{Ke}, \mathrm{B}$. and $\mathrm{Y}$. $\mathrm{Yu}, 2006$. The effect of issuing biased earnings forecasts on analysts' access to management and survival, Journal of Accounting Research 44(5), 965-999.

Lazear, E. P. and S. Rosen, 1981. Rank-order tournaments as optimum labor contracts, The Journal of Political Economy 89(5), 841-864.

Lim, T., 2001. Rationality and analysts' forecast bias, Journal of Finance 56, 369-385. 
Lin, H. W. and M. F. McNichols, 1998. Underwriting relationships, analysts' earnings forecasts and investment recommendations, Journal of Accounting and Economics 25(1), 101-127.

Ljungqvist, A., F. Marston, L. Starks, K. Wei and H. Yan, 2006. Conflicts of interest in sell-side research and the moderating role of institutional investors, Journal of Financial Economics $85,420-456$.

Loh, R. K. and R. M. Stulz, 2015. Is sell-side research more valuable in bad times? National Bureau of Economic Research No. w19778.

Lys, T. and S. Sohn, 1990. The association between revisions of financial analysts' earnings forecasts and security-price changes, Journal of Accounting and Economics 13(4), 341-363.

Mayew, W. J., 2008. Evidence of management discrimination among analysts during earnings conference calls, Journal of Accounting Research 46(3), 627-659.

McNichols, M. and P. O'Brien, 1997. Self-selection and analyst coverage, Journal of Accounting Research 35, 167-199.

Michaely, R. and K. L. Womack, 1999. Conflict of interest and the credibility of underwriter analyst recommendations, Review of Financial Studies 12(4), 653-686.

Mikhail, M. B., B. R. Walther and R. H. Willis, 1999. Does forecast accuracy matter to security analysts? Accounting Review 74, 185-200.

Nagel, S., 2012. Evaporating liquidity, Review of Financial Studies 25(7), 2005-2039.

Nyborg, K. G. and P. Östberg, 2014. Money and liquidity in financial markets, Journal of Financial Economics 112(1), 30-52.

O’Brien, P., 1988. Analysts' forecasts of earnings expectations, Journal of Accounting and Economics 10, 53-83.

Ramnath, S., S. Rock and P. Shane, 2008. The financial analyst forecasting literature: A taxonomy with suggestions for further research, International Journal of Forecasting 24, 34-75.

Richardson, S., S. H. Teoh and P. Wysocki, 1999. Tracking analysts' forecasts over the annual earnings horizon: Are analysts' forecasts optimistic or pessimistic? Working paper, University of Michigan.

Schipper, K., 1991. Analysts' forecasts, Accounting Horizons 5, 105-131.

Schwert, W., 2011. Stock volatility during the recent financial crisis, Journal of Banking and Finance 17, 789-805.

Soltes, E., 2014. Private interaction between firm management and sell-side analysts, Journal of Accounting Research 52(1), 245-272.

Stickel, S. E., 1990. Predicting individual analyst earnings forecasts, Journal of Accounting Research 28, 409-417.

Whaley, R. E., 2000. The investor fear gauge, Journal of Portfolio Management 26(3), 12-17.

Womack, K. L., 1996. Do brokerage analysts' recommendations have investment value? The Journal of Finance 51(1), 137-167.

Zhang, F., 2006. Information uncertainty and analyst forecast behavior, Contemporary Accounting Research 23(2), 565-590. 


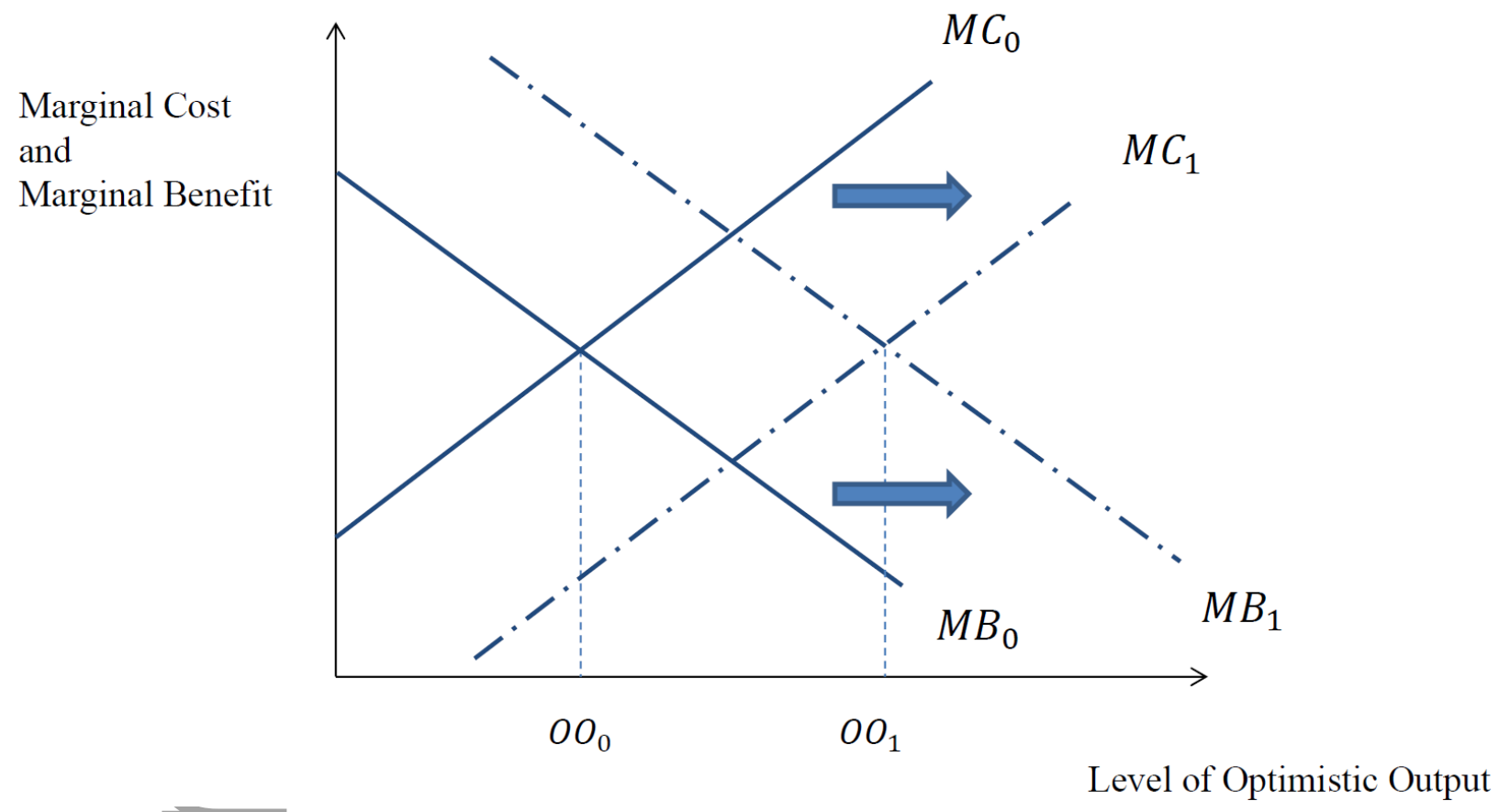

$M C_{0}$ and $M B_{0}$ denote the marginal cost curve and the marginal benefit curve when market uncertainty is low. $M C_{I}$ and $M B_{I}$ denote the marginal cost curve and the marginal benefit curve when market uncertainty is high. The downward shift in the marginal cost and the upward shift in the marginal benefit result in an increase in the level of optimistic output from $O O_{0}$ to $O O_{1}$ when market uncertainty increases.

Figure 2 Scatter plot of $V I X$ and aggregate analyst optimism 

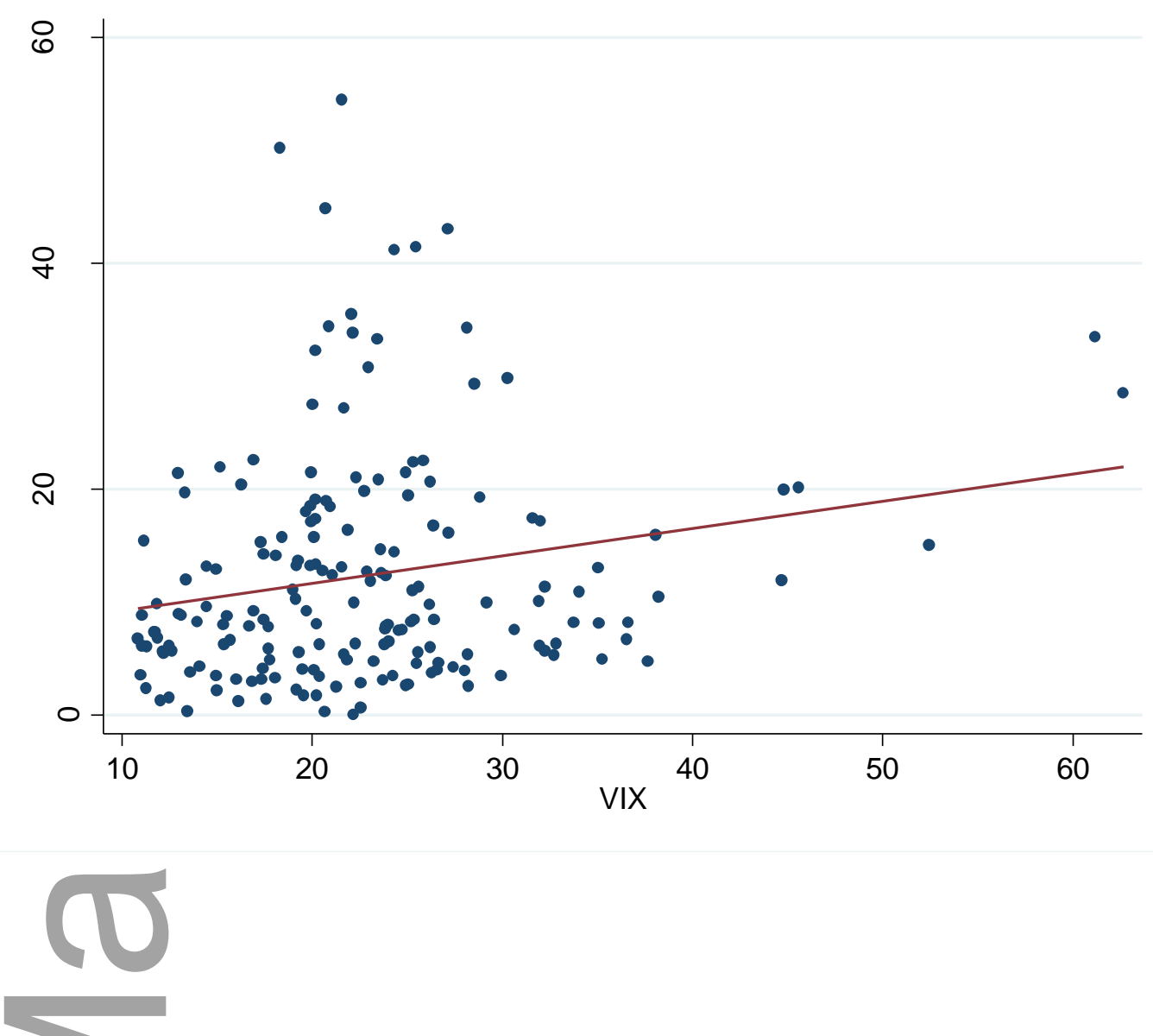

Figure 2 displays a scatterplot of the monthly VIX level and the monthly aggregate mean forecast error (Aggregate FE). Aggregate FE is the sum of all firm-level Consensus FE, which is the difference between the mean consensus forecast and actual earnings for firm $j$ in month $m$. A simple regression line shows a positive relationship between the VIX level and aggregate analyst-forecast optimism.

\section{Table 1 Summary statistics of key variables}

Panel A reports the descriptive statistics of the main variables. The sample period is from 1996 to 2012. Market uncertainty is measured using the average monthly VIX index one month prior to the analyst announcement date. Analyst-output variables include forecast error (FE); Optimistic Flag; stock recommendations (Recid); and buy, sell, hold percentage of stock recommendations (BuyPct, SellPct, HoldPct). FE is the forecast error (analysts' forecasts minus actual earnings), scaled by the stock price of year $t-1$ (multiplied by 100). Optimistic Flag is an indicator variable for the analyst forecast being greater than the actual earning. Recid is the numeric value of the stock recommendation, where strong buy $=5$, buy $=4$, hold $=3$, underperform $=2$, and sell $=1$. Buy, sell, and hold percentages of stock recommendations are ratios of buy, sell, and hold recommendations to total number of stock recommendations for the stock. In Panel B, analyst-output variables are subsampled into high- and low-market-uncertainty periods based on the highest (lowest) quintile levels of VIX, and t-tests are run across the subsamples.

Analyst-characteristic variables are Experience, Boldness, Rounding, Coverage, All-Star, and Brokerage Size. Experience is the log of the number of years an analyst issues a forecast for any given

This article is protected by copyright. All rights reserved. 
firm. Boldness is the percentage of bold earnings forecasts issued by analyst $i$ in year $t$. A forecast is defined as bold if the forecast is above both the analyst's prior forecast and the immediate consensus forecast before the forecast revision, or if the forecast is below both the analyst's prior forecast and the consensus forecast immediately before the forecast revision. Rounding is the percentage of rounded earnings forecasts issued by analyst $i$ in year $t$. A forecast is rounded if the forecast occurs at nickel intervals. Coverage is the number of firms covered by analyst $i$ in year $t$, in logs. All-Star is an indicator variable, which equals one if the analyst is included in the All-star analyst list by Institutional Investors magazine in year $t$. Brokerage Size is measured as the log of the number of analysts in a given brokerage firm in year $t$.

Firm-characteristic variables include Size, Market-to-Book Ratio, and Institutional Holdings. Size is the $\log$ of the market value of equity of firm $j$ in year $t-1$. Market/Book is calculated as the market value of the firm's equity at the end of year $t-1$ plus the difference between the book value of the firm's assets and the book value of the firm's equity in year $t-1$, divided by the book value of the firm's assets in year $t-1$. Institutional Holdings is the percentage of institutional investor holdings of firm $j$ in year $t-1$.

\section{Panel A}

\begin{tabular}{|c|c|c|c|c|}
\hline Market-uncertainty and analyst-output variables & & Mean & Median & Stddev \\
\hline VIX & & 20.401 & 19.261 & 7.825 \\
\hline Forecast error $(F E)$ & & 0.522 & 0 & 3.607 \\
\hline Optimistic flag & & 0.459 & 0 & 0.498 \\
\hline Stock recommendations (Recid) & & 4.343 & 4 & 0.962 \\
\hline Buy recommendation \% (BuyPct) & & 55.731 & 57.142 & 27.423 \\
\hline Sell recommendation \% (SellPct) & & 4.957 & 0 & 9.765 \\
\hline Hold recommendation \% (HoldPct) & & 39.315 & 40 & 24.392 \\
\hline \multicolumn{5}{|l|}{ Analyst-characteristic variables } \\
\hline Experience (in logs) & & 1.910 & 1.946 & 0.778 \\
\hline Boldness & & 0.150 & 0.178 & 0.150 \\
\hline Rounding & & 0.024 & 0.018 & 0.026 \\
\hline Coverage (in logs) & & 3.000 & 2.996 & 0.836 \\
\hline All-Star & & 0.136 & 0 & 0.343 \\
\hline Brokerage size (in logs) & & 3.678 & 3.829 & 1.029 \\
\hline \multicolumn{5}{|l|}{ Firm-characteristic variables } \\
\hline Size & & 7.667 & 7.581 & 1.788 \\
\hline Market/book & & 2.177 & 1.538 & 1.787 \\
\hline Institutional holdings & & 0.666 & 0.697 & 0.248 \\
\hline \multicolumn{5}{|l|}{ Panel B } \\
\hline Analyst-output variables & High $V I X \quad$ Low $V I X$ & & $\begin{array}{r}\mathrm{T}- \\
\text { statistic } \\
\end{array}$ & P-value \\
\hline Forecast error $(F E)$ & 0.581 & & 12.619 & $<0.001$ \\
\hline Optimistic flag & 0.470 & & 11.172 & $<0.001$ \\
\hline
\end{tabular}

This article is protected by copyright. All rights reserved. 
Stock recommendations (Recid)

Buy recommendation \% (BuyPct)

Sell recommendation \% (SellPct)

Hold recommendation \% (HoldPct)

\begin{tabular}{rrrr}
3.724 & 3.512 & 9.989 & $<0.001$ \\
56.333 & 49.708 & 48.4917 & $<0.001$ \\
4.993 & 6.2989 & -24.852 & $<0.001$ \\
38.6736 & 43.992 & -43.9739 & $<0.001$ \\
\hline
\end{tabular}

Table 2 Market uncertainty and forecast bias

Panel A: The effect of market uncertainty on analyst forecasts

Panel A reports the relationship between VIX and analyst-forecast error at the aggregate market level, firm level, and individual analyst level. Forecast error $(F E)$ is the difference between the analysts' forecasts and actual earnings, scaled by the stock price of year $t-1$ (multiplied by 100). In specification (1), the dependent variable is Aggregate FE, which is the sum of all firm-level Consensus $F E$ for each month $m$. In specification (2), the dependent variable is the Consensus FE, which is the difference between the mean consensus forecast and actual earnings for firm $j$ in July. In specification (3), the dependent variable is the individual analyst-forecast error and includes the analyst forecast closest to July but not after July (Hong and Kubik, 2003). In specifications (4)-(5), the dependent variable is an Optimistic Flag indicator variable, which equals one if the analyst forecast is greater than actual earnings. Specifications (1)-(4) report estimates using the linear probability model, and specification (5) reports estimates using the conditional logit model. Market uncertainty is measured using the average monthly VIX index one month prior to the analyst announcement date (scaled by 1/100). Analyst and firm-characteristic variables follow the definitions in Table 1. Specifications (2)-(5) include firm fixed effects. Standard errors are clustered by year in specification (1), by firm in specification (2), and by firm-analyst in specifications (3)-(5).

\begin{tabular}{|c|c|c|c|c|c|}
\hline Dependent variable & Aggregate $F E_{m t}$ & $\begin{array}{l}\text { Consensus } \\
F E_{\text {int }}\end{array}$ & $\begin{array}{l}\text { Individual } \\
F E_{\text {i.w. }}\end{array}$ & \multicolumn{2}{|c|}{ Optimistic Flag $_{i j m t}$} \\
\hline Sample & $\begin{array}{c}\text { All } \\
\text { months }\end{array}$ & July & July & July & July \\
\hline & (1) & (2) & (3) & (4) & (5) \\
\hline$V I X$ & 0.241 ** & $0.023 * * * *$ & $\begin{array}{r}0.858^{* * * *} \\
(0130\end{array}$ & $0.112^{* * * *}$ & $\begin{array}{r}0.548^{* * * *} \\
(0.193)\end{array}$ \\
\hline Coverage & & & $\begin{array}{r}-0.045^{* * * *} \\
(0.016)\end{array}$ & $\begin{array}{r}-0.011^{* * * *} \\
(0.002)\end{array}$ & $\begin{array}{r}-0.050^{* * * *} \\
(0.012)\end{array}$ \\
\hline Experience & & & $\begin{array}{r}0.032 * * * * \\
(0101\end{array}$ & $0.005^{* * * *}$ & $\begin{array}{r}0.023^{* * * *} \\
(0.008)\end{array}$ \\
\hline Horizon & & & $\begin{array}{c}0.102 * * \\
(0.049)\end{array}$ & $\begin{array}{r}-0.009 \\
(0.007)\end{array}$ & $\begin{array}{r}-0.040 \\
(0.048)\end{array}$ \\
\hline All-Star & & & $\begin{array}{r}-0.043 * * \\
(0.021)\end{array}$ & $\begin{array}{r}-0.065^{* * * *} \\
(0.007)\end{array}$ & $\begin{array}{r}-0.313 * * * \\
(0.045)\end{array}$ \\
\hline Boldness & & & $\begin{array}{r}-0.290 * * * \\
(0.048)\end{array}$ & $\begin{array}{r}0.105^{* * * *} \\
(0.033)\end{array}$ & $\begin{array}{r}0.477 \text { **** } \\
(0.182)\end{array}$ \\
\hline Rounding & & & $\begin{array}{c}0.635^{* *} \\
(0.263)\end{array}$ & $\begin{array}{r}-0.000 \\
(0.003)\end{array}$ & $\begin{array}{r}-0.000 \\
(0.016)\end{array}$ \\
\hline Brokerage Size & & & $\begin{array}{r}0.031^{* * * *} \\
(0.007)\end{array}$ & $\begin{array}{c}0.002 * * \\
(0.001)\end{array}$ & $\begin{array}{c}0.009 * \\
(0.005)\end{array}$ \\
\hline Size & & 0.066 & $0.191 * * *$ & $0.101 * * *$ & $0.486^{* * * *}$ \\
\hline
\end{tabular}

This article is protected by copyright. All rights reserved. 


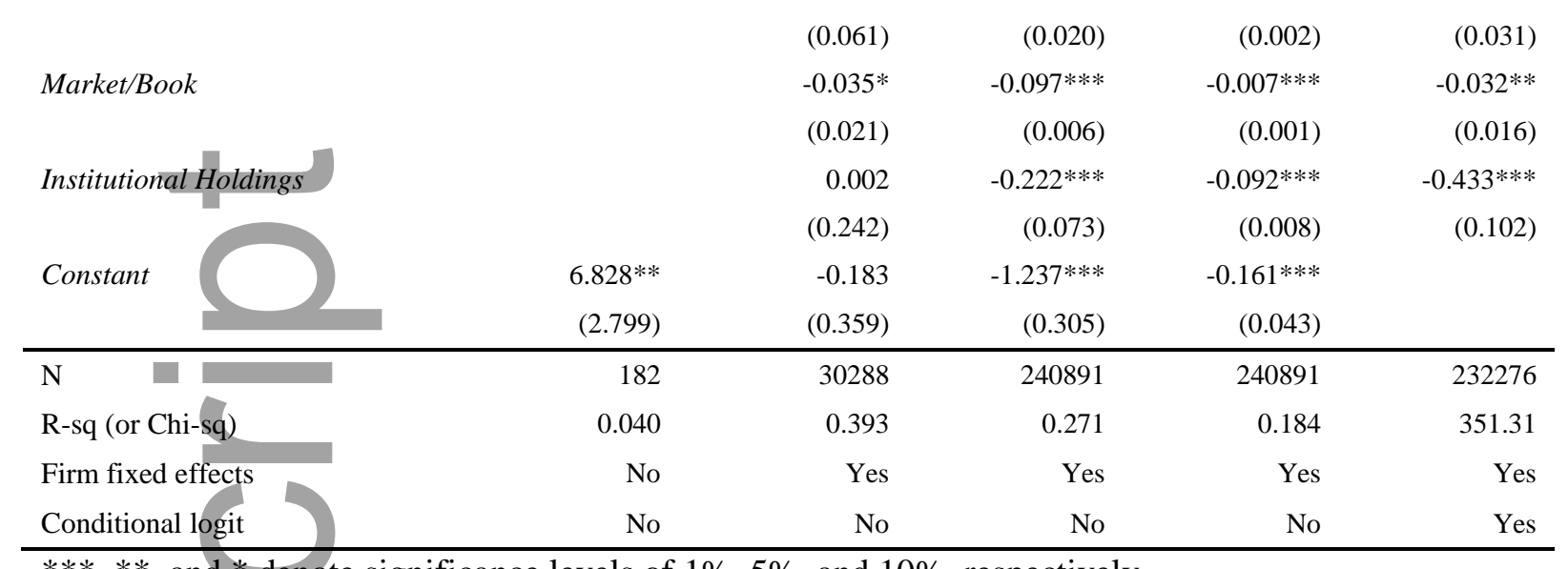

$* * *, * *$, and $*$ denote significance levels of $1 \%, 5 \%$, and $10 \%$, respectively.

Panel B: The effect of market uncertainty on analyst-forecast bias over different forecasting horizons

The dependent variable is the individual analyst-forecast error for firm $j$ in month $m$ in year $t$. Definitions of variables follow from Table 1. All specifications include firm fixed effects. Standard errors are clustered by firm and analyst.

\begin{tabular}{|c|c|c|c|c|}
\hline Dependent variable & \multicolumn{4}{|c|}{ Individual $F E_{i j m t}$} \\
\hline \multirow{2}{*}{ Horizon } & $0-90$ days & 91-180 days & $181-270$ days & 271-360 days \\
\hline & (1) & (2) & (3) & (4) \\
\hline \multirow[t]{2}{*}{$V I X$} & $1.803 * * *$ & $1.043 * * *$ & $1.459 * * *$ & $3.615^{* * *}$ \\
\hline & $(0.062)$ & $(0.105)$ & $(0.169)$ & $(0.156)$ \\
\hline \multirow{2}{*}{ Coverage } & 0.015 & $0.034 *$ & $0.065 * * *$ & $0.064 * * *$ \\
\hline & $(0.014)$ & $(0.018)$ & $(0.022)$ & $(0.024)$ \\
\hline \multirow[t]{2}{*}{ Experience } & 0.003 & 0.017 & $0.036 * * *$ & $0.051 * * *$ \\
\hline & $(0.008)$ & $(0.011)$ & $(0.013)$ & $(0.015)$ \\
\hline \multirow[t]{2}{*}{ Horizon } & $0.031 * * *$ & $0.398 * * *$ & $-0.121^{*}$ & 0.046 \\
\hline & $(0.007)$ & $(0.034)$ & $(0.067)$ & $(0.137)$ \\
\hline \multirow[t]{2}{*}{ All-Star } & -0.053 & $-0.202 * * *$ & $-0.334 * * *$ & $-0.764 * * *$ \\
\hline & $(0.038)$ & $(0.054)$ & $(0.068)$ & $(0.073)$ \\
\hline \multirow[t]{2}{*}{ Boldness } & $0.499 * *$ & $1.124 * * *$ & $1.248 * * *$ & $1.753 * * *$ \\
\hline & $(0.214)$ & $(0.301)$ & $(0.361)$ & $(0.407)$ \\
\hline \multirow[t]{2}{*}{ Rounding } & -0.013 & -0.017 & -0.036 & $-0.079 * *$ \\
\hline & $(0.017)$ & $(0.024)$ & $(0.030)$ & $(0.034)$ \\
\hline \multirow[t]{2}{*}{ Brokerage Size } & -0.003 & 0.004 & 0.014 & $0.027 * * *$ \\
\hline & $(0.005)$ & $(0.007)$ & $(0.009)$ & $(0.010)$ \\
\hline \multirow[t]{2}{*}{ Size } & 0.013 & $0.186^{* * *}$ & $0.221 * * *$ & $0.284 * * *$ \\
\hline & $(0.017)$ & $(0.022)$ & $(0.026)$ & $(0.029)$ \\
\hline \multirow[t]{2}{*}{ Market/Book } & $-0.014 * * *$ & $-0.035 * * *$ & $-0.074 * * *$ & $-0.145 * * *$ \\
\hline & $(0.005)$ & $(0.006)$ & $(0.007)$ & $(0.010)$ \\
\hline \multirow[t]{2}{*}{ Institutional Holdings } & 0.075 & -0.058 & -0.124 & -0.167 \\
\hline & $(0.072)$ & $(0.097)$ & $(0.105)$ & $(0.113)$ \\
\hline Constant & $-0.529 * * *$ & $-3.196 * * *$ & $-0.689 *$ & $-2.365 * * *$ \\
\hline
\end{tabular}

This article is protected by copyright. All rights reserved. 


\begin{tabular}{lrrrr} 
& $(0.125)$ & $(0.224)$ & $(0.409)$ & $(0.801)$ \\
\hline $\mathrm{N}$ & 299337 & 302081 & 302376 & 241338 \\
$\mathrm{R}$-sq & 0.233 & 0.282 & 0.300 & 0.296 \\
Firm fixed effects & Yes & Yes & Yes & Yes \\
\hline
\end{tabular}

$* * *, * *$, and $*$ denote significance levels of $1 \%, 5 \%$, and $10 \%$, respectively.

Table 3 Market uncertainty and stock recommendations

Panel A: Individual analyst stock recommendations

Panel A reports the relationship between VIX and individual analyst stock recommendations. The dependent variable is Recid, which is the numeric value of the stock recommendation, where strong buy $=5$, buy $=4$, hold $=3$, underperform $=2$, and sell $=1$. Market uncertainty is measured using the average monthly VIX index one month prior to the analyst announcement date (scaled by 1/100). Analyst- and firm-characteristic variables follow the definitions in Table 1. All specifications include firm fixed effects. Standard errors are clustered by firm and analyst.

\begin{tabular}{|c|c|c|}
\hline r & (1) & (2) \\
\hline VIX & $\begin{array}{r}0.139 * * * \\
(0.035)\end{array}$ & $\begin{array}{r}0.203 * * * \\
(0.052)\end{array}$ \\
\hline Coverage & & $\begin{array}{l}-0.012 \\
(0.008)\end{array}$ \\
\hline Experience & & $\begin{array}{r}0.015^{* *} \\
(0.008)\end{array}$ \\
\hline All-Star & & $\begin{array}{r}-0.065^{* * * *} \\
(0.010)\end{array}$ \\
\hline Boldness & & $\begin{array}{r}0.012 \\
(0.023)\end{array}$ \\
\hline Rounding & & $\begin{array}{r}-0.463 * * * \\
(0.122)\end{array}$ \\
\hline Brokerage Size & & $\begin{array}{r}-0.064 * * * \\
(0.004)\end{array}$ \\
\hline Size & & $\begin{array}{r}-0.020 * * * \\
(0.007)\end{array}$ \\
\hline Market/Bo & & $\begin{array}{r}0.086 * * * \\
(0.003)\end{array}$ \\
\hline Institutional Holdings & & $\begin{array}{r}-0.491 * * * \\
(0.028)\end{array}$ \\
\hline Constant & $\begin{array}{r}3.736 * * * \\
(0.007)\end{array}$ & $\begin{array}{r}4.157 * * * \\
(0.059)\end{array}$ \\
\hline $\mathrm{N}$ & 200908 & 84858 \\
\hline R-sq & 0.107 & 0.157 \\
\hline Firm fixed effects & Yes & Yes \\
\hline
\end{tabular}

, and $*$ denote significance levels of $1 \%, 5 \%$, and $10 \%$, respectively.

Panel B: Firm-level stock-recommendation percentages

Panel B reports the relationship between VIX and firm-level stock-recommendation percentages. The dependent variable is the percentage of buy, sell, or hold recommendations for firm $j$ in July of year $t$. In specification (1), the dependent variable is the percentage of buy recommendations of a stock. In specification (2), the dependent variable is the percentage of sell recommendations of a stock. In specification (3), the dependent variable is the percentage of hold recommendations of a stock. 
Market uncertainty is measured using the average monthly VIX index one month prior to the analyst announcement date (scaled by 1/100). Firm-characteristic variables follow the definitions in Table 1 . All specifications include firm fixed effects. Standard errors are clustered by firm.

\begin{tabular}{|c|c|c|c|}
\hline Dependent variable & BuyPct & SellPct & HoldPct \\
\hline & (1) & (2) & (3) \\
\hline VIX & $\begin{array}{r}0.410 * * * \\
(0.026)\end{array}$ & $\begin{array}{r}-0.145^{* * *} \\
(0.010)\end{array}$ & $\begin{array}{r}-0.265 * * * \\
(0.024)\end{array}$ \\
\hline Size & $\begin{array}{r}0.049 * * * \\
(0.005)\end{array}$ & $\begin{array}{r}-0.013 * * * \\
(0.002)\end{array}$ & $\begin{array}{r}-0.036 * * * \\
(0.004)\end{array}$ \\
\hline Market/Book & $\begin{array}{r}0.019 * * * \\
(0.003)\end{array}$ & $\begin{array}{r}-0.003 * * * \\
(0.001)\end{array}$ & $\begin{array}{r}-0.016^{* * * *} \\
(0.003)\end{array}$ \\
\hline Institutional Holdings & $\begin{array}{r}-0.214 * * * \\
(0.013)\end{array}$ & $\begin{array}{r}0.056^{* * *} * \\
(0.004)\end{array}$ & $\begin{array}{r}0.157 * * * \\
(0.011)\end{array}$ \\
\hline Constant & $\begin{array}{r}0.184 * * * \\
(0.029) \\
\end{array}$ & $\begin{array}{r}0.150^{* * * *} \\
(0.010) \\
\end{array}$ & $\begin{array}{r}0.665^{* * * *} \\
(0.026) \\
\end{array}$ \\
\hline $\mathrm{N}$ & 31017 & 31017 & 31017 \\
\hline R-sq & 0.445 & 0.353 & 0.428 \\
\hline Firm fixed effects & Yes & Yes & Yes \\
\hline
\end{tabular}

$* * *, * *$, and $*$ denote significance levels of $1 \%, 5 \%$, and $10 \%$, respectively.

Table 4

Analyst turnover, market uncertainty, and optimism

\section{Panel A: Industry turnover}

This table reports the relationship between VIX, forecast accuracy, and analyst leaving the profession (denoted as "Industry Turnover" hereafter). The dependent variable is Industry Turnover, which equals one if the analyst stops making earnings forecasts in year $t$. Flag is a dummy variable that equals one if the analyst is in the highest $10 \%$ in the distribution of average forecast optimism across analysts in year $t-1$. Average forecast optimism is the average of an indicator variable for the analyst forecast being above the consensus forecast. Market uncertainty is measured using the average annual $V I X$ index in year $t-1$, scaled by $1 / 100$. Analyst-characteristic variables follow the definitions in Table 1. All specifications are estimated using a logit model with robust standard errors.

\begin{tabular}{|c|c|c|c|c|}
\hline Dependent variable & \multicolumn{4}{|c|}{ Industry turnover } \\
\hline 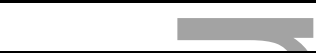 & (1) & (2) & (3) & (4) \\
\hline$V I X$ & $\begin{array}{r}1.316 \\
(3.622)\end{array}$ & $\begin{array}{r}1.660 \\
(3.725)\end{array}$ & $\begin{array}{r}1.614 \\
(3.702)\end{array}$ & $\begin{array}{r}1.504 \\
(3.710)\end{array}$ \\
\hline Flag & & $\begin{array}{r}0.221 \\
(0.175)\end{array}$ & $\begin{array}{r}0.221 \\
(0.175)\end{array}$ & $\begin{array}{r}0.176 \\
(0.190)\end{array}$ \\
\hline Flag*VIX & & $\begin{array}{r}-1.609 * * \\
(0.715)\end{array}$ & $\begin{array}{r}-1.722 * * \\
(0.732)\end{array}$ & $\begin{array}{r}-1.540 * * \\
(0.732)\end{array}$ \\
\hline Coverage & & & $-0.125 * *$ & -0.095 \\
\hline
\end{tabular}

This article is protected by copyright. All rights reserved. 


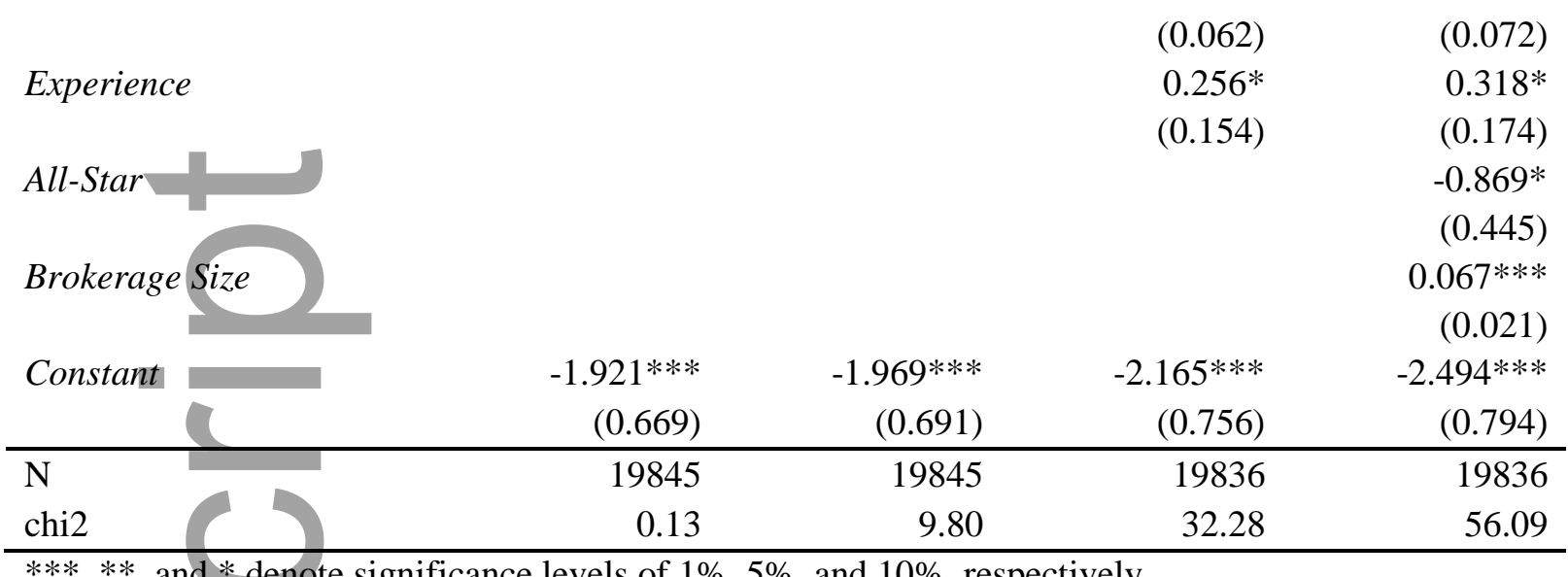

\section{Panel B: Job turnover}

This table reports the relationship between VIX, forecast accuracy, and analyst job turnover. Job turnover is defined as analysts' changing employment. In specifications (1)-(3), the dependent variable is the Moye Down indicator variable, which equals one if the analyst moves down from a large brokerage firm to a small brokerage firm in year $t$. In specifications (4)-(6), the dependent variable is the Move $U p$ indicator variable, which equals one if the analyst moves up from a small brokerage firm to a large brokerage firm in year $t$. Flag is a dummy variable that equals one if the analyst is in the highest $10 \%$ in the distribution of average forecast optimism across analysts in year $t$ 1. Average forecast optimism is the average of an indicator variable for the analyst forecast being above the consensus forecast. Market uncertainty is measured using the average annual VIX index in year $t$ - 1 . Analyst-characteristic variables follow the definitions in Table 1. All specifications are estimated using a logit model with robust standard errors.

\begin{tabular}{|c|c|c|c|c|c|c|}
\hline \multirow[t]{2}{*}{ Dependent variable } & \multicolumn{3}{|c|}{ Move Down } & \multicolumn{3}{|c|}{ Move Up } \\
\hline & $(1)$ & (2) & (3) & (4) & (5) & (6) \\
\hline$V I X$ & $\begin{array}{r}2.167 \\
(3.456)\end{array}$ & $\begin{array}{r}2.130 \\
(3.435)\end{array}$ & $\begin{array}{r}2.033 \\
(3.416)\end{array}$ & $\begin{array}{r}0.913 \\
(2.111)\end{array}$ & $\begin{array}{r}0.945 \\
(2.124)\end{array}$ & $\begin{array}{r}1.100 \\
(2.096)\end{array}$ \\
\hline Flag & $\begin{array}{r}0.242 \\
(0.163)\end{array}$ & $\begin{array}{r}0.238 \\
(0.161)\end{array}$ & $\begin{array}{r}0.219 \\
(0.176)\end{array}$ & $\begin{array}{r}-0.756 \\
(0.875)\end{array}$ & $\begin{array}{r}-0.695 \\
(0.862)\end{array}$ & $\begin{array}{r}-0.622 \\
(0.864)\end{array}$ \\
\hline Flag *VIX & $\begin{array}{r}-1.605^{* *} \\
(0.680)\end{array}$ & $\begin{array}{r}-1.709 * * \\
(0.695)\end{array}$ & $\begin{array}{r}-1.615^{* *} \\
(0.678)\end{array}$ & $\begin{array}{r}2.372 \\
(3.619)\end{array}$ & $\begin{array}{r}2.612 \\
(3.560)\end{array}$ & $\begin{array}{r}2.346 \\
(3.551)\end{array}$ \\
\hline Coverage & & $\begin{array}{r}-0.125^{* *} \\
(0.059)\end{array}$ & $\begin{array}{r}-0.113 \\
(0.073)\end{array}$ & & $\begin{array}{r}0.520 * * * \\
(0.152)\end{array}$ & $\begin{array}{r}0.468 * * * \\
(0.171)\end{array}$ \\
\hline Experience & & $\begin{array}{r}0.228 \\
(0.157)\end{array}$ & $\begin{array}{l}0.298^{*} \\
(0.173)\end{array}$ & & $\begin{array}{r}-0.400 * * \\
(0.202)\end{array}$ & $\begin{array}{r}-0.499 * * * \\
(0.192)\end{array}$ \\
\hline All-Star & & & $\begin{array}{l}-0.788^{*} \\
(0.406)\end{array}$ & & & $\begin{array}{r}0.838 * * * \\
(0.217)\end{array}$ \\
\hline Brokerage Size & & & $\begin{array}{r}0.162 * * * \\
(0.041)\end{array}$ & & & $\begin{array}{r}-0.020 \\
(0.083)\end{array}$ \\
\hline Constant & $\begin{array}{r}-1.999 * * * \\
(0.666)\end{array}$ & $\begin{array}{r}-2.139 * * * \\
(0.720)\end{array}$ & $\begin{array}{r}-2.790 * * * \\
(0.671)\end{array}$ & $\begin{array}{r}-4.601 * * * \\
(0.453)\end{array}$ & $\begin{array}{r}-5.196 * * * \\
(0.747)\end{array}$ & $\begin{array}{r}-4.985 * * * \\
(0.775)\end{array}$ \\
\hline $\mathrm{N}$ & 19845 & 19836 & 19836 & 19845 & 19836 & 19836 \\
\hline
\end{tabular}

This article is protected by copyright. All rights reserved. 
$* * *, * *$, and $*$ denote significance levels of $1 \%, 5 \%$, and $10 \%$, respectively.

\section{Table 5 Trading activity, market uncertainty, and optimism}

This table reports the relationship between VIX, analyst optimism, and trading activity. Panel A reports the relationship between trading volume and optimistic forecasts. Panel B reports the relationship between trading volume and optimistic recommendations. The dependent variable is the average abnormal trading volume (in logs) around analyst-announcement windows ([0, 1] days). Abnormal trading volume is the difference between trading volume and expected trading volume, which is the average trade volume (in logs) of the firm 30 days prior to the announcement date ([-35, 6] days). Forecast accuracy and stock recommendations, as well as analyst and firm-characteristic variables, follow the definitions in Table 1. Analyst characteristics include Coverage, Experience, AllStar, Boldness, Rounding, and Brokerage Size. Firm characteristics include Size, Market/Book, and Institutional Holdings. All specifications include firm fixed effects. Standard errors are clustered by firm and analyst.

Panel A

\begin{tabular}{|c|c|c|}
\hline Forecast error & $(1)$ & $(2)$ \\
\hline VIX & $\begin{array}{r}-0.791 * * * \\
(0.022)\end{array}$ & $\begin{array}{r}-0.707 * * * \\
(0.022)\end{array}$ \\
\hline$F E$ & $\begin{array}{r}-0.004 * * \\
(0.002)\end{array}$ & $\begin{array}{r}-0.005 * * * \\
(0.002)\end{array}$ \\
\hline$F E^{*} V I X$ & $\begin{array}{r}0.015^{* *} \\
(0.007)\end{array}$ & $\begin{array}{r}0.021 * * * * \\
(0.007)\end{array}$ \\
\hline $\begin{array}{l}\text { Analyst characteristics } \\
\text { Firm characteristics } \\
\text { Firm fixed Effects } \\
\end{array}$ & $\begin{array}{r}\text { Yes } \\
\text { No } \\
\text { Yes } \\
\end{array}$ & $\begin{array}{l}\text { Yes } \\
\text { Yes } \\
\text { Yes } \\
\end{array}$ \\
\hline \multicolumn{3}{|l|}{ Panel B } \\
\hline Individual stock recommendations & $(1)$ & (2) \\
\hline VIX & $\begin{array}{r}-0.251^{*} \\
(0.149)\end{array}$ & $\begin{array}{r}-0.244 \\
(0.150)\end{array}$ \\
\hline Recid & $\begin{array}{r}-0.040 * * * \\
(0.014)\end{array}$ & $\begin{array}{r}-0.040 * * * \\
(0.014)\end{array}$ \\
\hline $\operatorname{Recid}^{*} V I X$ & $\begin{array}{c}0.103^{*} \\
(0.055) \\
\end{array}$ & $\begin{array}{l}0.102 * \\
(0.055) \\
\end{array}$ \\
\hline Analyst characteristics & Yes & Yes \\
\hline Firm characteristics & No & Yes \\
\hline Firm fixed Effects & Yes & Yes \\
\hline
\end{tabular}

$* * *, * *$, and $*$ denote significance levels of $1 \%, 5 \%$, and $10 \%$, respectively.

Table 6 Cross-Sectional Characteristics, Market Uncertainty, and Optimism

This table reports the relationship between the cross-sectional firm/analyst characteristics of the degree of firm-level information/analyst experience, VIX, and analyst optimism. Specifications (1)-(4) examine the effect of firm-level information on the relationship between VIX and analyst optimism, and specifications (5)-(8) examine the effect of analysts' experience on the relationship between $V I X$ and analyst optimism. The dependent variable is the individual analyst-forecast error $(F E)$ in specifications (1)-(2) and (5)-(6). In specifications (3)-(4) and (7)-(8), the dependent variable is analyst stock recommendation (Recid). The degree of firm-level information (firm-level information versus market-level information) is measured by the correlation between firm return and market return 
(Frankel, Kothari, and Weber, 2006). $R S Q$ is the R-squared value from the market model, regressing the value-weighted market return on firm return for firm $j$ in year $t$. INEXP is an indicator variable that equals one if the analyst is defined as inexperienced, i.e., if the number of years since the analyst's first forecast year is below the median of eight years. Analyst characteristics include Coverage, Experience, All-Star, Boldness, Rounding, and Brokerage Size. Firm characteristics include Size, Market/Book, and Institutional Holdings. Analyst- and firm-characteristic variables follow the definitions in Table 1. All specifications include firm fixed effects. Standard errors are clustered by firm and analyst.

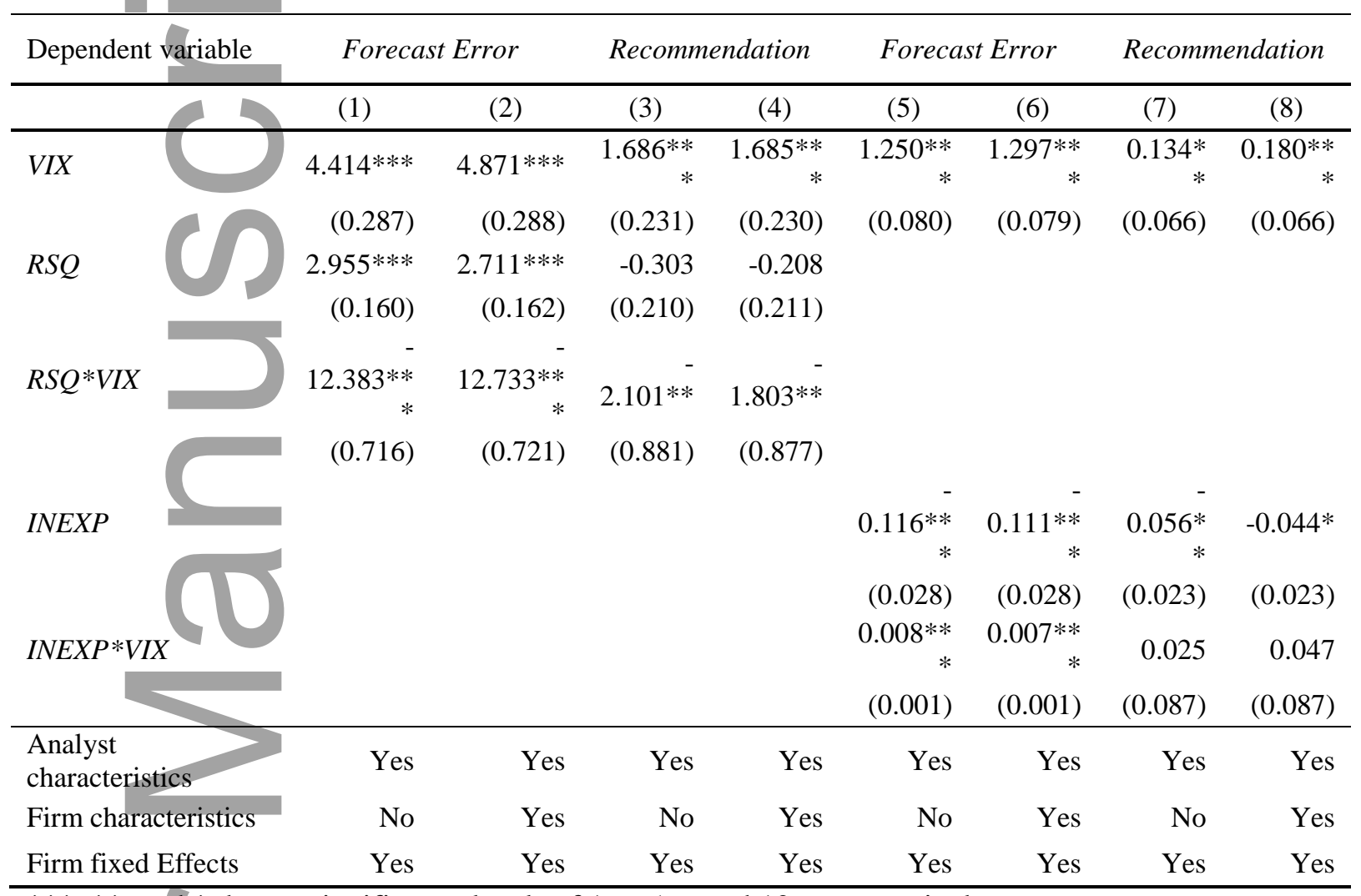

$* * *, * *$, and $*$ denote significance levels of $1 \%, 5 \%$, and $10 \%$, respectively.

\section{Table 7 Analyst experience, optimism, and job outcomes}

This panel reports the effect of analysts' experience on the relationship between VIX, analyst optimism, and job outcomes. In specifications (1)-(4), the dependent variable is the Industry Turnover indicator variable, which equals one if the analyst stops making earnings forecasts in year $t$. In specifications (5)-(8), the dependent variable is the Move Down indicator variable, which equals one if the analyst moves down from a large brokerage firm to a small brokerage firm in year $t$. Flag is a dummy variable that equals one if the analyst is in the highest $10 \%$ in the distribution of average forecast optimism across analysts in year $t-1$. Average forecast optimism is the average of an indicator variable for the analyst forecast being above the consensus forecast. The analyst is defined as experienced if the number of years since his or her first forecast year is above the median of eight years, and estimation samples are subsampled by the median. Analyst characteristics include Coverage, Experience, All-Star, Boldness, Rounding, and Brokerage Size, and are included in specifications (2), (4), (6), and (8). Analyst-characteristic variables follow the definitions in Table 1. All specifications are estimated using a logit model with robust standard errors. 


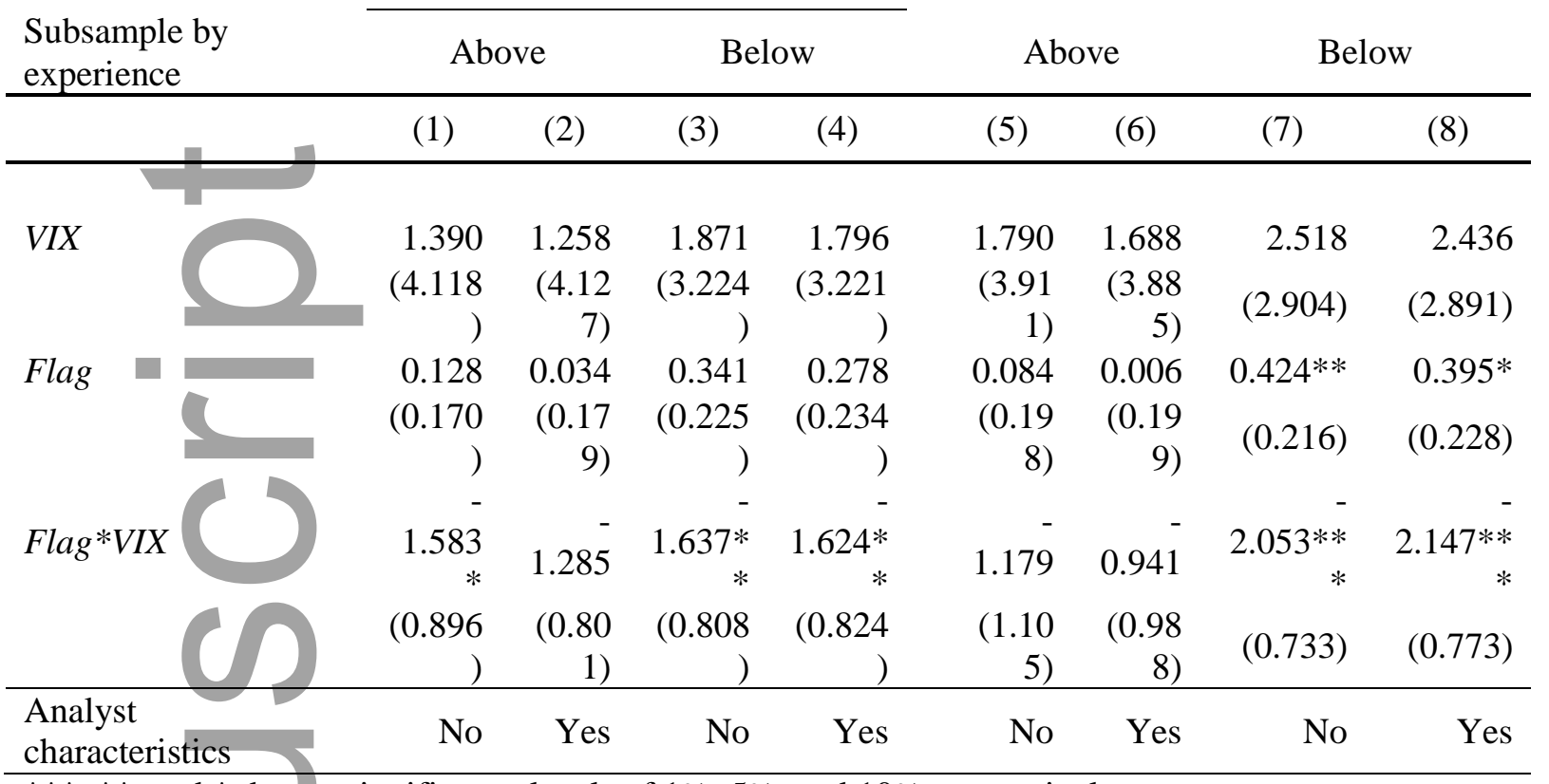

$* * *, * *$, and $*$ denote significance levels of $1 \%, 5 \%$, and $10 \%$, respectively.

Table 8 Analyst following and forecast frequency

This table reports the relationship between VIX and the number of analysts issuing earnings forecasts and stock recommendations, as well as the relationship between VIX and analyst-forecast frequency. In specification (1), the dependent variable is the number of analysts issuing earnings forecasts for firm $j$ in year $t$. In specification (2), the dependent variable is the number of analysts issuing buy, sell, or hold recommendations for firm $j$ in year $t$. In specification (3), the dependent variable is the natural logarithm of the total number of forecasts issued by analyst $i$ in year $t$. In specification (4), the dependent variable is the natural logarithm of the average number of forecasts issued by analyst $i$ per firm $j$ covered in year $t$. Market uncertainty is measured using the average monthly VIX index one month prior to the analyst announcement date. Firm and analyst-characteristic variables follow the definitions in Table 1. Specifications (1)-(2) include firm fixed effects, and specifications (3)-(4) include analyst fixed effects. In specifications (1)-(2), standard errors are clustered by firm and year. In specifications (3)-(4), standard errors are clustered by firm and analyst.

\begin{tabular}{|c|c|c|c|c|}
\hline Dependent variable & $\begin{array}{c}\text { Number of Analysts Issuing } \\
\text { Earnings Forecasts }\end{array}$ & $\begin{array}{l}\text { Number of Analysts } \\
\text { Issuing }\end{array}$ & \multicolumn{2}{|c|}{ Number of Forecasts } \\
\hline & (1) & (2) & (3) & (4) \\
\hline$V I X$ & $\begin{array}{r}0.460 * * \\
(0.233)\end{array}$ & $\begin{array}{l}0.370^{*} \\
(0.203)\end{array}$ & $\begin{array}{r}0.004 * * * \\
(0.001)\end{array}$ & $\begin{array}{l}0.001 * \\
(0.000)\end{array}$ \\
\hline Size & $\begin{array}{r}1.680^{* * *} \\
(0.105)\end{array}$ & $\begin{array}{r}2.170^{* * * *} \\
(0.077)\end{array}$ & & \\
\hline Market/Book & $\begin{array}{r}-0.175^{* *} \\
(0.078)\end{array}$ & $\begin{array}{r}-0.350 * * * \\
(0.032)\end{array}$ & & \\
\hline Institutional Holdings & $\begin{array}{r}0.912 * * * \\
(0.255)\end{array}$ & $\begin{array}{r}2.731 * * * \\
(0.166)\end{array}$ & & \\
\hline Coverage & & & $\begin{array}{r}-0.089 * * * \\
(0.014)\end{array}$ & $\begin{array}{r}0.022 * * * \\
(0.008)\end{array}$ \\
\hline Experience & & & $\begin{array}{r}0.004 \\
(0.027)\end{array}$ & $\begin{array}{r}0.008 \\
(0.017)\end{array}$ \\
\hline Boldness & & & $\begin{array}{r}-0.533 * * * \\
(0.163)\end{array}$ & $\begin{array}{l}-0.143 \\
(0.096)\end{array}$ \\
\hline
\end{tabular}

This article is protected by copyright. All rights reserved. 
Rounding

\begin{tabular}{rr}
$0.474 * * *$ & 0.010 \\
$(0.018)$ & $(0.011)$ \\
$0.051^{* *}$ & -0.007 \\
$(0.023)$ & $(0.015)$ \\
$-0.016^{*}$ & $-0.008^{*}$ \\
$(0.008)$ & $(0.005)$ \\
$2.617 * * *$ & $1.246 * * *$ \\
$(0.054)$ & $(0.031)$ \\
\hline 29291 & 29291 \\
0.668 & 0.587 \\
No & No \\
Yes & Yes
\end{tabular}

All-Star

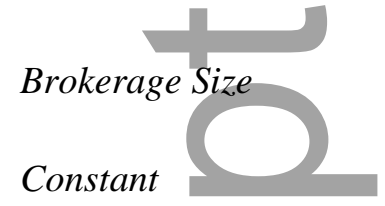

$-5.348 * * *$

(0.603)

$\mathrm{N}$

$(0.461)$

0.820

27052

0.760

Yes

No

Yes

Analyst fixed effects

No

$* * *, * *$, and $*$ denote significance levels of $1 \%, 5 \%$, and $10 \%$, respectively.
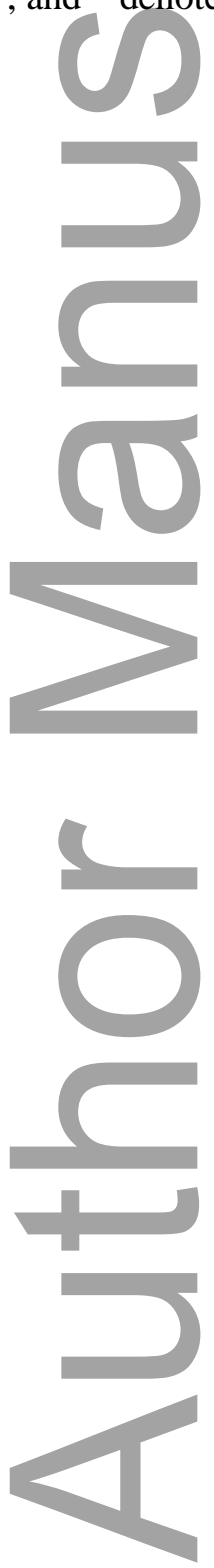

This article is protected by copyright. All rights reserved. 